\title{
GESTOS DE DESAFÍO SOCIAL Y SEXUAL. RESILIENCIA E IDENTIDAD EN LOS VIDEOCLIPS \\ DE (ME LLAMO) SEBASTIÁN (2011-2020)
}

\author{
Domingo Sola Antequera* \\ Universidad de La Laguna
}

\section{RESUMEN}

La obra del músico chileno (me llamo) Sebastián es una muestra constante de su posicionamiento vital. Canciones de letras crudísimas en primera persona, melodías arrebatadoras, referencias al género, a la identidad y a la diversidad sexual, o el arte como reivindicación envuelto en un pop altamente emocional, son elementos referenciales de su proyecto. Rompiendo con lo normativo, su propuesta estética y su puesta en escena son ingredientes indisolubles de su obra, por lo que sus conciertos y videoclips constituyen la prolongación natural de esos gestos de desafío constante. Este trabajo, partiendo de estos últimos, pretende reflexionar sobre todo ello.

Palabras clave: (me llamo) Sebastián, género, identidad, pop emocional, videoclips, LGTB+.

\section{CHALLENGING SOCIAL AND SEXUAL BEHAVIOUR. RESILIENCE AND IDENTITY IN THE MUSIC VIDEOS OF (ME LLAMO) SEBASTIÁN (2011-2020)}

\section{Abstract}

The work of the chilean musician (me llamo) Sebastián is a constant proof of his vital position. Raw lyrics, captivating melodies, references to identity, gender and sexual diversity are part of his proposal on art as a claim, as a vindication. All this, developed in a highly emotional pop, are references to his project. Breaking with the normative, he creates an aesthetic proposal and a careful staging that seek to take the spectator to a universe of his own. Gigs and music videos constitute a natural extension of those constant challenging gestures. Based on those clips this paper proposes to reflect upon this musician risky offer. Keywords: (me llamo) Sebastián, gender, identity, emotional pop, music videos, LGBT+. 


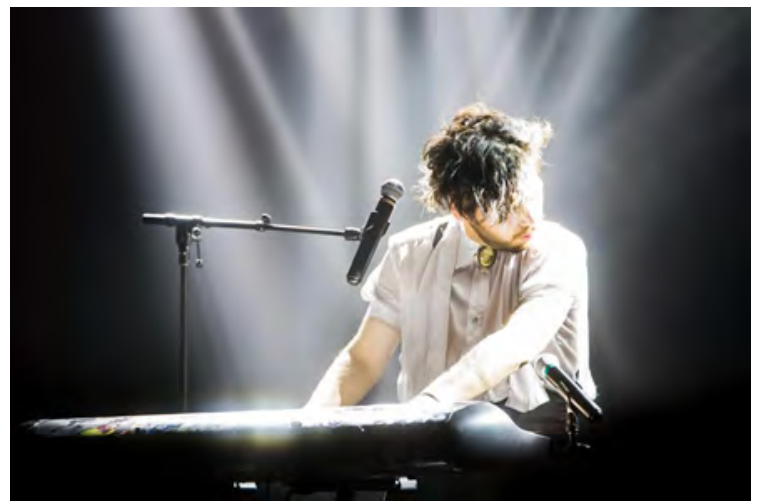

(me llamo) Sebastián. Concierto en el Teatro Cariola, Santiago de Chile, octubre de 2017. Foto: Loreto Plaza.

La felicidad no es siempre la mejor manera de ser feliz Donde viven los monstruos (Where The Wild Things Are, Spike Jonze 2009)

La escena musical chilena de la última década es una de las más interesantes e innovadoras no solo del Cono Sur, sino de todo el panorama de la música en español. Nombres como Javiera Mena, Alex Anwandter, Gepe, Dënver, Cristóbal Briceño y sus Ases Falsos, Francisca Valenzuela, Los Bunkers, Protistas, Marineros o Sebastián Sotomayor -de quien nos ocuparemos en estas páginas- son solo algunos de los artistas con mayor proyección dentro y fuera de sus propias fronteras.

Sotomayor lidera un proyecto personal denominado (me llamo) Sebastián, que quizá hasta el momento no haya tenido la misma repercusión que alguno de los anteriormente citados, probablemente por el carácter mucho más intimista de su propuesta, alejada de otras destinadas a priori a un triunfo masivo.

Ser abiertamente gay en un país homófobo ha hecho definir su música en relación con su orientación sexual, cuando en realidad lo que ofrece es un pop altamente emocional que no se adscribe a etiqueta alguna. Al contrario, su música defiende la diversidad, en homenaje a la libertad en mayúsculas desde un posicionamiento profundamente ideológico.

Desde este punto de vista parecería que su trabajo podría estar abocado al fracaso, pero parafraseando a Warhol, éste es solo una oportunidad diferente y no un punto muerto. De alguna forma crear desde ese lugar lo convierte en un artista genderfuck que propone historias de resiliencia, de determinación y transformación, así como de soledad, alienación y lucha personal.

\footnotetext{
* Departamento de Historia del Arte y Filosofía, e-mail: dsola@ull.edu.es.
} 
Es así como su obra, al igual que en ocasiones también lo es la de Alex Anwandter, se opone al binarismo tradicional entre lo masculino y lo femenino, situándose en los márgenes del mismo, de los roles de géneros modelados sobre lo heteronormativo.

En 1990, tres años después de su nacimiento, Queer Nation difundiría en Nueva York un Manifiesto que podría asumir palabra a palabra el músico santiaguino en su decidida apuesta por cuestionar las construcciones sociales que oprimen a cualquier minoría sexual. El siguiente fragmento tiene su origen en ello, habiendo nacido para dotar de sentido a la lucha contra la opresión «hetero» en plena crisis del sida:

Ser queer no tiene que ver con un derecho a la privacidad; tiene que ver con la libertad de ser públicos, de ser simplemente lo que somos. Significa combatir cada día la opresión, la homofobia, el racismo, la misoginia, la intolerancia de los religiosos hipócritas y nuestro odio interiorizado [...]. Tiene que ver con permanecer en los márgenes que nos definen; tiene que ver con follarse el género.

Este cuestionamiento lo ha convertido en una figura pública que busca provocar reflexión en quienes escuchan sus canciones, o al menos violentar a aquéllos que lo miran de reojo a través de su propia vulnerabilidad.

La fragilidad, así como la falta de pudor en el relato y en la exhibición, hace de su propuesta artística un modelo de reivindicación personal desde la disidencia de aquéllos que se sienten al margen del sistema y necesitan encontrar nuevas formas de relación y una manera alternativa de integración. Como más de una vez repetirá, el compromiso conforma así un elemento consustancial en el mensaje que pretende transmitir.

En ese compromiso subyacen las siempre complejas relaciones humanas, los fundamentos de la identidad y las fronteras de la sexualidad. Todo gira en torno a estas construcciones sociales ${ }^{1}$ y a las estrategias de representación -de comunicación- con las que hacerlas públicas a través de su música, de sus textos y de sus performances. En su caso, y en palabras de Beatriz Preciado, «la homosexualidad se vuelve el nuevo rostro de la normalización identitaria [...]. Se trata [...] de fabricar otras formas de placeres, relaciones, coexistencias, vínculos, amores e intensidades» (2012: pos. 2223-2395).

Por tanto, todo ello ha contribuido a construir una persona singular y una carrera compacta llena de atrevimientos, conflictos y aprendizaje, pero que además es capaz de cuestionar las relaciones de poder que han ayudado a cimentar unas categorías en proceso de transformación.

Todos estos apuntes sobre la orientación de su proyecto artístico parecerían sugerir que lo dirigiese a un público potencial y limitado, a un nicho de mercado específico, pero en realidad la sublimación de las emociones convierte su mensaje en universal, permitiendo sentirse identificadas a muchas más personas, pues pareciera que las canciones nos interpelasen directamente, que nos hablasen, que se dirigiesen

\footnotetext{
${ }^{1}$ Aunque resulte obvio que la homosexualidad no lo sea.
} 


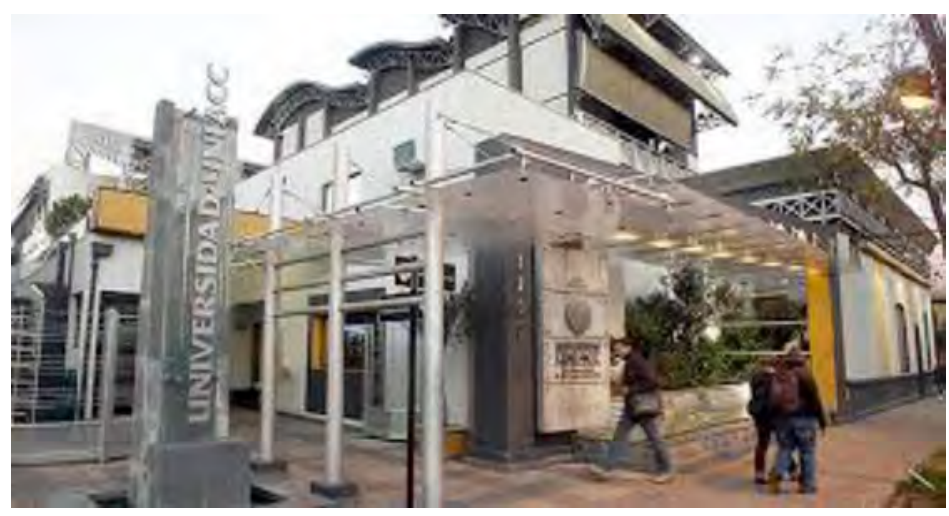

UNIACC.

a nuestras propias experiencias, a nuestra cabeza. Por ello, Sotomayor cree «que las letras comprometidas pueden generar un cambio en las personas que las escuchan" (Littlebab, 2016), teniendo «la firme convicción de que en las cosas cotidianas uno puede hacer una metáfora universal de todo» (García, 2016).

Pero antes de seguir profundizando en los orígenes creativos del chileno conozcamos cuándo y cómo surgió su alter ego musical, así como sus referentes más evidentes.

\section{1. (ME LLAMO) SEBASTIÁN}

En cualquier pequeña referencia biográfica del artista siempre se arranca de la insistencia paterna, tras oírlo cantar en la ducha, para que participase en diferentes programas televisivos cazatalentos de los que no parece tener demasiado buen recuerdo, pues arrastra, desde bien joven, ciertos complejos sobre su físico que no le ayudan a creerse su capacidad para triunfar, llegando a decir más tarde de sí mismo: «Soy feo, soy gordo, soy fleto ${ }^{2}$, no tengo plata... Como que encapsulo un montón de grupos disidentes, todos marginados» (Ocampo Cea, 2014).

Completa su formación musical en la academia de canto de Luis Jara en Providencia con sólo trece años, una comuna al noroeste del área metropolitana de Santiago, para terminarla en la Universidad de Artes, Ciencias y Comunicación (UNIACC) de la misma localidad. Un centro especialmente orientado hacia las artes y al mundo audiovisual, bajo el lema «Bienvenido a Crear», que aunque no se encuentra especialmente bien posicionada a nivel nacional, posee un canal de televisión y

2 Coloquialmente en Chile, homosexual. 

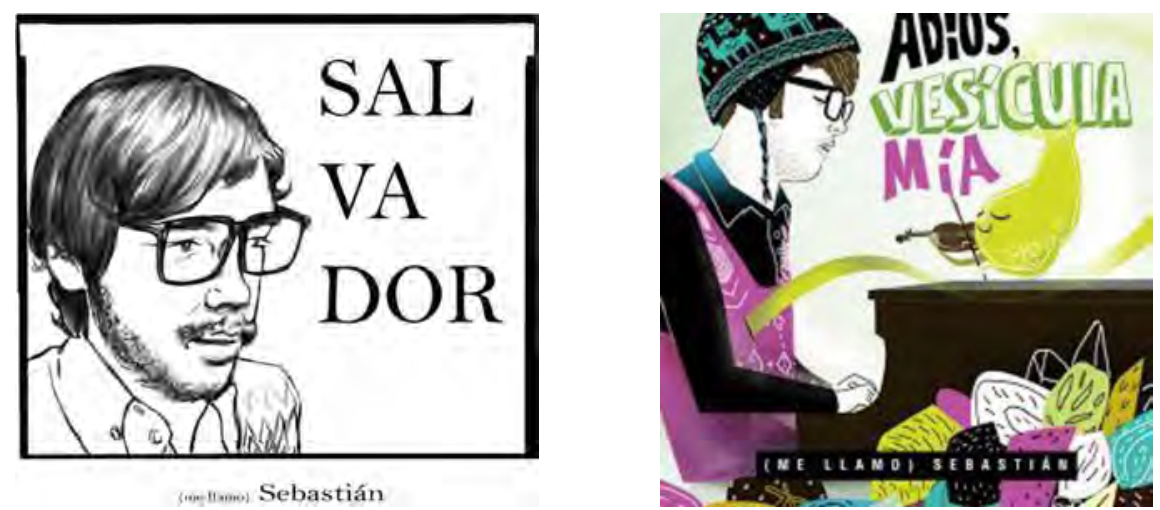

una estación de radio que les permite difundir proyectos y creaciones. Entre ambas experiencias había incluso llegado a participar en el Nile Song Festival for Children, siguiendo esa dinámica competitiva que marcaría su infancia y su adolescencia.

Tras su paso por la UNIACC será cuando decida comenzar su carrera como músico en solitario y adoptar el nombre por el que se le va a empezar a conocer artísticamente. De hecho, con solo 18 años parece tener listas sus primeras canciones, vehículo para exorcizar todas sus frustraciones.

En 2010 lanzaría su primer disco, Salvador. Trece cortes con una producción austera y un estilo más cercano al universo cantautor, íntimo, melódico, sencillo, incluso disperso en su discurso, que al pop de sus obras posteriores, especialmente a las dirigidas por Cristian Heyne. De hecho, en el material promocional en Bandcamp lo dedica a "las cosas simples de la vida», desnudando claramente sus intenciones y exponiendo en el propio proceso creativo sus inseguridades, sus anhelos y sus ansiedades.

Desde esa primera placa nos muestra una de sus mayores virtudes, convertir su propia vida y su singular personalidad en material creativo, en confesiones en primera persona sobre la base de un piano que resulta un sutil contrapunto a su voz. Comienza así un camino marcado por la honestidad que avanzará, en los años siguientes, por veredas menos trilladas.

Su siguiente paso lo dará solo un año más tarde con la publicación de Adiós, vesícula mía. Diez nuevas canciones que no desentonan con las anteriores, aunque se muestre algo más alternativo, y que esta vez dedica a «todos los que nos hemos sentido injustamente extirpados». Con ellas sigue en la línea de encontrar su propio discurso, tratando de ser consecuente con él. En los primeros versos de "Venir», single extraído del disco, deja claro su posicionamiento:

Considera que los miedos son los mismos

Para todos

Pero cada uno debe escoger

Si quieres yo te acompaño 
Para ver que te

Quedes tranquilo hasta que lo entiendas

$\mathrm{Y}$ es que cada uno debe escoger

Bien agarradas de nuestras almas

Los cerebros

$Y$ toda la mugre se queda entremedio

La mente universal nos entiende

Nos prefiere

Si hubiese una guerra

Porque ella siempre está de lado del amor

Y al vernos eso queda más que claro

No le importa

Que un par de gente imbécil nos invente

Una Biblia o una ley

Y recuerda que ya vamos harto lejos

Y no tenemos ninguna enfermedad

No!

Con esta declaración de principios abre el LP, que más tarde sería compilado en una Antología poética por el sello Quemarropa. «Me tiene loco la libertad del cuerpo, el respeto a la diferencia... Siempre trato de cuestionar las cosas, onda las relaciones humanas, por ejemplo», declararía en una entrevista concedida a Andrea Ocampo unos años más tarde (2014). Sin duda, arranca así uno de tantos ejercicios en los que se aplica en criticar a la sociedad contemporánea, focalizando en la de su país transformada en satélite de su propio planeta, para la que propone un modelo futuro en el que cualquiera de las minorías sexuales esté perfectamente integrada. Este constructo nos hace partícipes claramente de su pensamiento en el ámbito de las teorías queer, especialmente cuando éstas se interrogan sobre la ontología de la sexualidad y del género.

El siguiente paso en su carrera va de la mano de un productor que cambiará totalmente su sonido, proyectándolo hacía un público con el que antes no había conseguido conectar. Nos referimos a Fernando Mujica, conocido en el medio como Mowat, quien asentado en Berlín abraza a una nueva generación de músicos chilenos a quienes produce obras seminales, caso de Felipe Cardenasso, Diego Peralta o el que nos ocupa, entre otros.

En una entrevista ofrecida en 2015 a Marisol García para Súper 45, plataforma multimedia dedicada a difundir la música independiente desde el país andino, expresa su fascinación por la escena nacional vista desde la distancia:

Hay algo que pasa ahora en Chile, algo súper. Para mí es impresionante, porque incluso estando acá en Europa descubro cosas chilenas que me vuelan la cabeza, y que probablemente son más interesantes que lo que pueda escuchar en Berlín. No puede negarse que el medio musical chileno es precario, pero también creo que ha crecido tanto que hoy puede pelear de igual a igual con cualquiera. Sinceramente, 


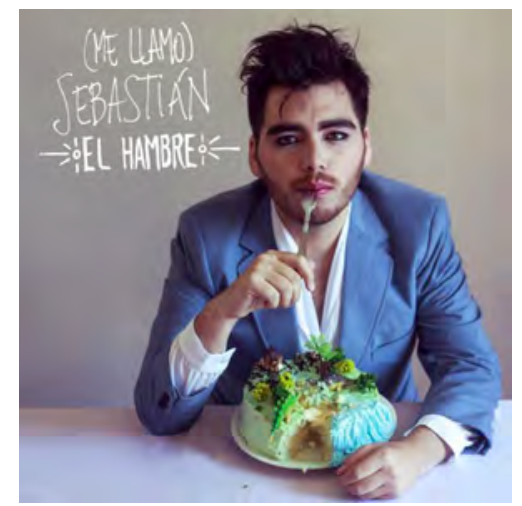

me siento como bendecido por estar cerca de esta generación específica de músicos (García, 2015).

Mowat ayuda a dar forma a su tercer disco en 2013, El hambre. Las historias personales siguen ahí, pero la manera de proyectarlas ha cambiado radicalmente, dejando atrás la estética de cantautor para adentrarse en un universo pop brillante, complejo en su producción, de sonoridades más densas y atractivas, que realzan la intensidad de la voz del artista. La honestidad de su propuesta por fin se cristalizaba así en un embalaje mucho más vibrante que los anteriores, siendo aplaudida por la crítica y colocando esta obra entre las más importantes de la década en su país. Además, el productor le pide ampliar sus referencias artísticas, obligándole a escuchar a Tori Amos, Regina Spektor y Rufus Wainwright antes de arrancar el proyecto, convirtiéndose éste último en un paralelo notorio, especialmente cuando se pierde en un sutil barroquismo, en el amor a la comedia musical o en cierto enamoramiento de su propio fraseo, que solo Cristian Heyne ha podido puntualmente frenar.

Canciones como «Varita mágica», «Hormonas» o «Niños rosados» acabaron de imponer la etiqueta de pop gay a su repertorio, con la que no comulga aunque tampoco rechaza, lo que expresaría públicamente en varias ocasiones.

No es que yo quiera componer cosas del mundo gay o ponerle voz a lo que no tiene voz. Yo creo que me siento parte de ese grupo, soy gay y vivo en Santiago, vivo en este país y las cosas que me afectan son las mismas que afectan a todos [...]. Entonces, si yo en mis canciones puedo denunciar eso, obvio que lo voy a hacer, pero no lo hago por levantar una bandera de lucha, sino porque es lo que veo como ser humano. Creo que si trabajara en cualquier otra cosa, hablaría de lo mismo, pondría los mismos temas sobre la mesa (Riveros, 2017).

Lo especial de la grabación recae en convertirse en un paisaje que transita sobre su niñez, y de cómo el pasado es el poso emocional del presente y de su posicionamiento vital. Los discos nos muestran a un Sebastián cada vez más empoderado 
y se acaban convirtiendo en retratos de sus estados de ánimo. De hecho, la tercera de las canciones citadas se tornaría en un auténtico himno, el primero de su carrera.

Niñas rosadas y niños de azul

Si hay montones de colores

porque solo dos combinaciones

Puedo portarme como un Superman

Y otro día en la noche

soy Gatúbela ${ }^{3}$ y voy a bailar con

Nińos rosados y nińas de azul

con millones de colores

sin vergüenza de combinaciones

donde las reinas se saben pintar

y los príncipes se pueden agarrar a besos

si ellos quieren

Las palabras que proyecta el cantante sobre la heteronormatividad de los roles, se interpreten o no correctamente -de lo que se quejará en algunas ocasiones-, exponen claramente cómo los factores socioculturales que todos heredamos son los que construyen y nos imponen nuestra identidad de género. Identidad que no puede ser definida por las actividades que realicemos o por nuestro sexo biológico, a pesar de que partiendo de él hayamos todos creado nuestra propia personalidad, lo que puede haber costado crecer con los afectos y las emociones mutilados.

De nuevo, la resistencia aparece como un tema constante, como parte indisoluble de su dinámica como compositor. Desde ella se enfrenta a los discursos dominantes en los media, a las prácticas de consumo y hasta al propio poder establecido. Ya Derrida o Foucault habían indicado claramente que no existía una verdad absoluta y Sotomayor se aplica en deconstruir lo que parece una heterosexualidad «obligatoria».

En 2015 publicaría La belleza, una producción de Sebastián Wallerstein, Andrés Landon y el propio autor, que diseña un nuevo marco creativo para el universo del compositor chileno. En él todas las ambiciones frustradas de trabajos anteriores se proyectan en un disco mucho más ambicioso, enérgico y positivo, con en el que incluso exhibe una propuesta estética más definida, pues apenas la había cultivado hasta ese momento.

Con un «dedicado a los que siempre fuimos los últimos en ser escogidos en la clase de educación física», parece volver a transitar el filo del fracaso como motor creativo, lo que se acentúa en esa imagen de príncipe circunspecto de ojos húmedos y ego herido desde la que nos observa en la portada, obra del fotógrafo Jon Jacobsen, en la que sublima su obsesión por la belleza.

Es ésta una estrategia interpretativa que pone en valor la exclusión, la soledad, la confusión, incluso el romanticismo enfermizo del perdedor, exteriorizando

3 Catwoman en Latinoamérica. 


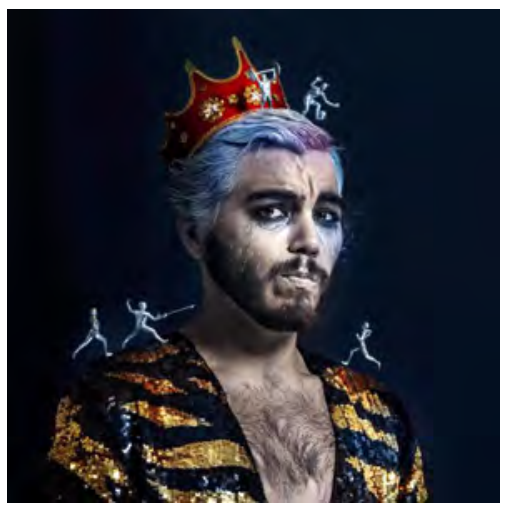

La belleza (2015).

lo que suele llamar como "un diario de vida musicalizado». En este caso expande su universo hablando sobre el mundo de los escorts masculinos o el maltrato, transitando el pudor sin echar mano de metáforas que oculten su biografía o sus inseguridades personales y físicas, que parecen ser un compañero de viaje del que no puede desprenderse. No hay drama sin conflicto y éste subyace en todas las composiciones, se exprese desde el dolor o desde el gozo. Los temas que interpreta junto a Gepe, «Masaje», y Mon Laferte, «Está bien ser lo peor», consolidan esa faceta derrotista y a la vez lúdica del compositor, o, como dice Jorge Rubio Soto (2015) en una crítica al álbum, «reitera las claves para ser un ganador siendo un perdedor». Quizá ése sea su estilo, el del fracaso, el de conectar con un pasado traumático que comienza a superarse tras retratar el antiglamur del artista.

El disco abre con un nuevo himno, "Baila como hombre», homenaje a Daniel Zamudio, joven asesinado en 2012, con apenas 24 años, por un grupo de neonazis en un parque de Santiago. Es una canción contra el olvido, rescatando la memoria no solo de Zamudio, sino de todos aquéllos apaleados hasta morir por su condición sexual. El joven acabará convertido en símbolo contra la violencia homofóbica, e incluso Alex Anwandter se inspirará en él para levantar su único largometraje, Nunca vas a estar solo (2016).

El caso despertó a la sociedad chilena y propulsó el debate sobre la homofobia y sobre la necesidad de leyes que se enfrentasen a este tipo de discriminación y delito, ya que no existían en el país andino. El mismo ańo de su fallecimiento, con Sebastián Piñera de presidente, se promulgó la denominada Ley Zamudio, que establecía medidas contra las consideradas discriminaciones arbitrarias y planteaba un procedimiento judicial para restablecer el derecho ante esos actos, aplicando medidas sancionadoras. La ley sigue siendo hoy cuestionada por su escasa efectividad, puesto que no ha frenado los casos de violencia contra la comunidad LGTBI+, sino que han ido en aumento. Constanza Valdés, letrada y activista trans, explica las razones de ello: 


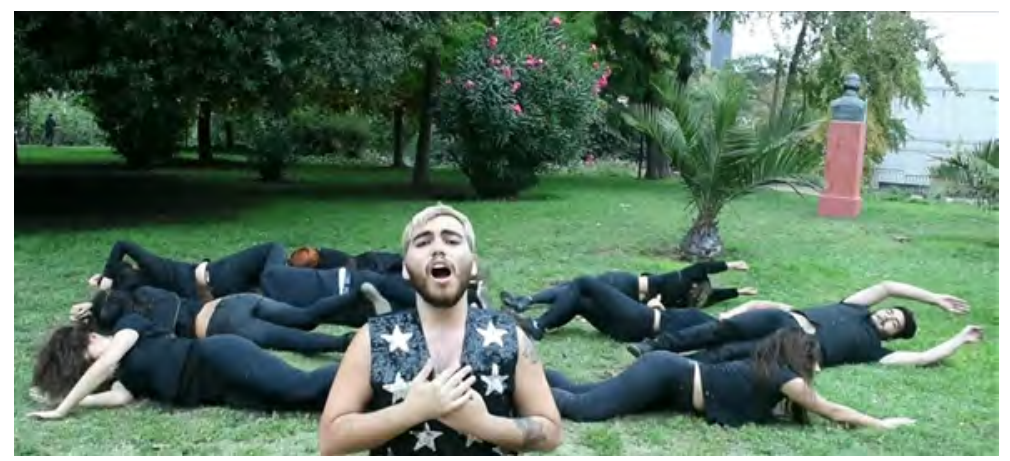

Fotograma del lipdub de «Baila como hombre».

Chile en verdad está cambiando [...], hay más gente que apoya y que entiende. Sin embargo, esto también implica que hay gente que no piensa así y se envalentona con las olas fascistas, grupos religiosos y personajes que se encargan de difundir discursos de odio, con quienes se sienten legitimados para poder actuar violentamente (León, 2019).

El videoclip de «Baila como hombre» comienza con un texto sobre un fondo negro que en silencio, con respeto y vergüenza, se expresa con repulsa y miedo contenidos, con indignación ante la violencia y la muerte:

Mientras estás viendo este video

Nos siguen insultando en la calle por nuestros amores

Nos siguen mandando al infierno por defender la libertad de los cuerpos

Nos siguen criminalizando por evadir un pasaje que es un robo en nuestras caras Nos siguen negando nuestro derecho a educarnos

Nos siguen tratando de decir cómo debemos vivir.

Estas palabras nos muestran a un Sebastián que se siente y forma parte de la disidencia, de quienes viven al margen de los códigos de lo normativo, y son un ejemplo obvio de cómo el arte se torna vindicación.

La apuesta aumenta con los dos siguientes sencillos que antecederán a su último, por ahora, larga duración. La producción iría de la mano de Cristian Heyne, quien ya había firmado obras tan importantes y de tanta repercusión como Otra Era, de Javiera Mena, y Audiovisión, de Gepe. El cambio vuelve a ser notable, entre otras cosas por la introducción de un pop que apuesta por la electrónica indie y que acerca las canciones a un sonido mucho más contemporáneo. La química con el cantante parece total, pero el disenso llegará pronto siendo desplazado del que sería su próximo trabajo, La sombra, donde Sotomayor vuelve a retomar completamente las riendas del proyecto. 

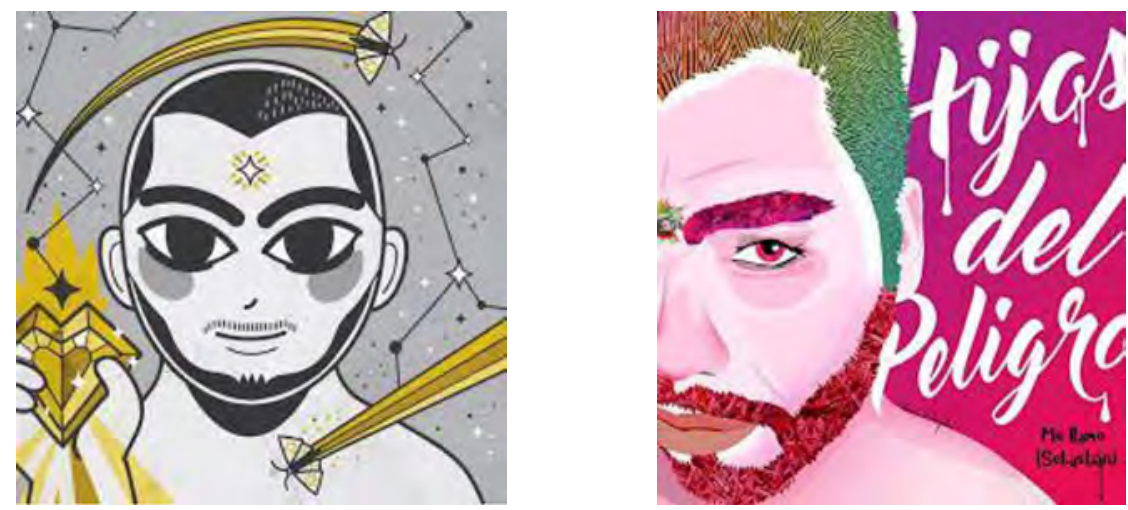

«Las polillas» e «Hijos del peligro» son las dos piezas dirigidas por Heyne, minimizando la tendencia natural al barroquismo y a la intensidad en el verbo del cantante, aconsejándole un cambio de rumbo a la hora de componer:

Tú ya no necesitas cantar todo lo que puedes cantar, no necesitas decir todas las palabras que quieres decir, tampoco necesitas poner todos los acordes que quieres. Necesitas armar algo con lo mínimo, para que el mensaje sea directo, saca los adornos (Morales, 2016).

No obstante, lo que parecía un proyecto a largo plazo se rompe sin explicaciones por ambas partes, dejando huérfanas dos de las mejores canciones de su repertorio. En la segunda ahonda y continúa en la lucha contra la homofobia y en la primera se sobrepone a la idea del amor romántico, construyendo una melodía minimalista que se pierde mientras lamenta la soledad de quien siempre tiene la sensación de que ninguna buena acción queda sin castigo, que todos los esfuerzos son pocos, independientemente de la dedicación, el esfuerzo y la pasión que se ponga en ellos, como una polilla que se golpea una y otra vez contra un foco que no consigue traspasar. "¿Cómo puedes pensar que yo no te quiero cuidar aún?», se lamenta mientras la canción se apaga en un fade out, no sin antes haberla dedicado «a los que siempre intentamos con todo corazón, pero nunca es suficiente». Es Sebastián en su versión más vulnerable.

En 2018 La sombra cierra una etapa. Supone un reencuentro con lo más visceral de su persona: estados de ánimo de perfil bajo, arrepentimiento y la muerte planeando entre sus pulsiones. Para llegar hasta aquí debe asumir que no escribe para los demás, sino para sí mismo, que no tiene la necesidad de "querer agradarle a otra gente». Como concepto es un cambio radical, pues por primera vez se siente libre frente a la creación musical.

Este ejercicio de cierta soberbia artística propone unas canciones alejadas de la brillantez de las obras anteriores (de hecho, desnuda y regraba las piezas de Heyne 
para que cuadren con el espíritu de las nuevas), turbias, desnudas de artificio, paridas desde las entrañas, con un sonido sucio, áspero, molesto e incomprendido por gran parte de los fans que esperaban una continuación de La belleza o de "Hijos del peligro». La producción, aunque conceptualmente vaya en paralelo al espíritu de la obra, acaba lastrando las canciones, que no terminan nunca de levantarse y brillar, ni de convencer para convertirse en nuevos himnos.

Richard Villegas (2017) apunta en la misma dirección en su reseña del disco para Remezcla: «His decision to revert from pop production to his sparse original compositions has sadly rendered the songs unfineshed and unresolved, though they now reflect the broader minimalism of the record».

Tras la salida del LP en algunas páginas se referirán a él como el «quirky misfit» (extravagante inadaptado) de la escena indie chilena, alabando el cambio existencialista de la prosa del compositor, el retrato de su pasado más traumático, su lírica sofocante para espíritus heridos y pesimistas.

Jung, que es discípulo de Freud, decía que tenemos muchos arquetipos dentro de nosotros y uno de esos es la sombra, que es toda nuestra parte oscura, nuestros impulsos. Entonces este disco tiene harto que ver con eso. Que hay una rabia generalizada que he ido acumulando, una pena [...]. Quiero que cuando me muera, porque todos nos vamos a morir, me gustaría que alguien pudiera acceder a esta música y encontrar como a un ser humano que se entregó entero (Equipo Rock\&Pop, 2017).

El single de presentación, "Edificios», es un perfecto ejemplo de esta obra diferente, de este discurso sobre la fragilidad y de la parálisis emocional que exhibe Sotomayor. Este sucumbir a lo oscuro de su alma resulta una ciénaga de afectos y un continuo enfrentamiento, pues «la sombra que desde chico te persigue se va haciendo más grande hasta que te das cuenta que tienes que enfrentarla» (Reyes, 2017).

En medio de esta catarsis personal va a recibir uno de los golpes más duros de su carrera y no vino de la mano de su proyecto musical, sino de lo que en cierto modo lo rodea. En noviembre de 2017 el guitarrista de su banda, Pablo Gálvez Zúńiga, fue acusado de presunto acoso sexual por Camila Oyarce, quien aseguraba que los hechos estaban expuestos en una demanda que se encontraba en curso y acogida por la Fiscalía de Nuñoa. Sotomayor optó por no intervenir en el asunto diciendo que no era él quien debía pronunciarse sobre la inocencia o culpabilidad de su músico, sino que debía esperar y colocarse del lado de la verdad. En realidad, la relación de amistad que le unía al guitarrista bloqueó su imparcialidad.

Esta manera de afrontar un tema tan delicado le costaría un linchamiento público en el que incluso llegó a participar Alex Anwandter, quien lanzaría dardos envenenados violentamente contra Sotomayor:

Citar tus letras como evidencia de tu feminismo es, aparte de un tanto ridículo (o bueno, ridículo), una reacción tibia e insensible ante la verdadera situación importante: el/los abusos cometidos. Ese Pablo Gálvez cometió un crimen, en lo que a mí respecta. Lo de Me llamo Sebastián, me parece más narcisismo que ser un encubridor, en lo personal (Equipo Rock\&Pop, 2017); 


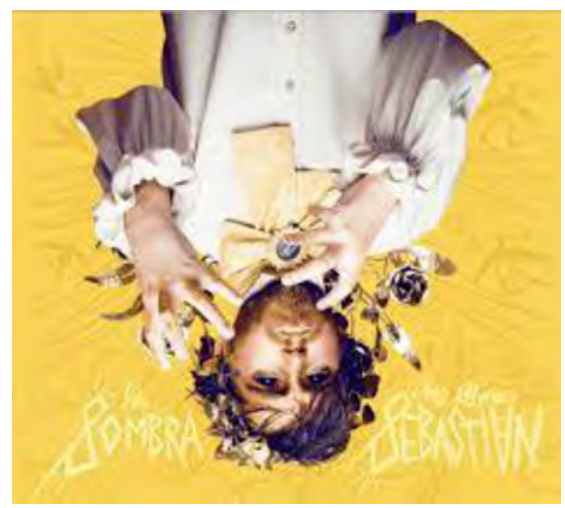

mientras que una mucho más conciliadora Javiera Mena prefería afirmar: «Estamos acostumbrados a tirar piedras y me parece bien esperar» (Garrido, 2017).

El daño estaba hecho y era irreversible, las pullas contra su persona le habían convertido en un enemigo del feminismo, tanto que decidiría marcharse a México "por miedo", para retomar allí su carrera y encontrarse a sí mismo en una nueva etapa que intentaba dejar atrás la excesiva exposición mediática que había tenido en su propio país tras la denuncia.

Yo sé que los que escuchen mis canciones saben de la lucha contra la violencia, contra los prejuicios, contra la mentira, es uno de los mayores ejes de mi trabajo. Es lo que trato de vivir todos los días, en cada acto que hago y me destroza ver comentarios malintencionados vinculándome a la violencia. Por favor, agarren su corazón antes de escribir algo en internet, no saben el daño que le puede causar a una persona.

Con este comunicado en Facebook (Del Real, 2017), Sotomayor intentaba defenderse de las acusaciones, mostraba signos evidentes de su vulnerabilidad, de la facilidad para difamar en las redes y del dolor que esos meses de acoso le habían causado.

Antes de comenzar de nuevo decidiría estrenar un último trabajo que debía entenderse como exteriorización del viacrucis por el que recién había pasado. Tres canciones en colaboración con Martín Berrios y Max Munizaga, que en el videoclip de presentación, dirigido por Matías Bize, conformaban una secuencia única con títulos en la línea de la angustia y la tristeza que había sufrido, solo, incomprendido: «El dolor es un momento», «El valor»y «La fogata».

Si no estamos ni completos que al menos nos abracemos Que al menos nos abracemos si no estamos ni completos Vamos hacia el hoyo negro 

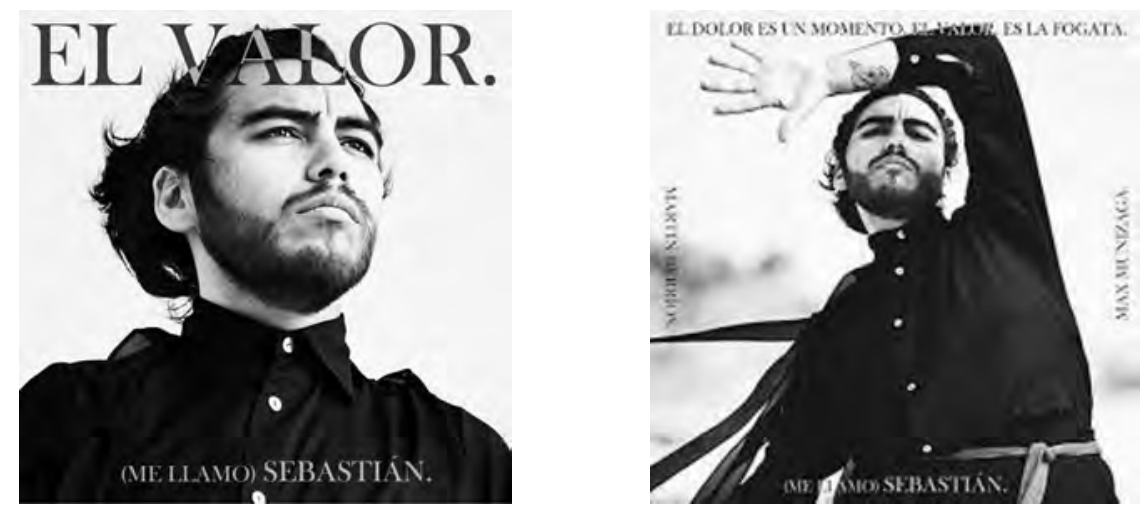

que cargamos en el pecho

¿Por qué lucho contra el tiempo

si el dolor es un momento?

(...)

Recordemos que el valor vendrá

desde el mismo lugar

que el miedo, oh oh oh, oh oh

(...)

Durante tantos años

hemos construido un altar a la luz

Están tirando piedras

Lo escupen, lo encadenan

lo ponen en la cruz

(...)

¿Qué alumbrar si no es siendo una fogata?

Véanla arder

Véala prender

Véanse gritar y que esta estaca nos hace polvo a los dos

No distingue si eres plegaria o maldición

Si das el mal o das el don

Si eres tirano o eres un dios

Estos fragmentos exorcizan esos meses de desesperación y de frustración. Ahora las preocupaciones están por encima de las cuestiones sobre la identidad, el género, la libertad o la rebelión personal, sus letras definitivamente se han instalado en la rabia y hablan desde ella, desde la frustración. Lo personal está más presente que nunca y las inseguridades parecen haber aumentado y dirigirse mucho más allá que a las singularidades de su físico, que, tras su éxito y reconocimiento, parecen haberse desvanecido. En una entrevista ofrecida a Andrés del Real, en la que utiliza la palabra depresión para definir su estado vital, apunta a todo ello (2018): 


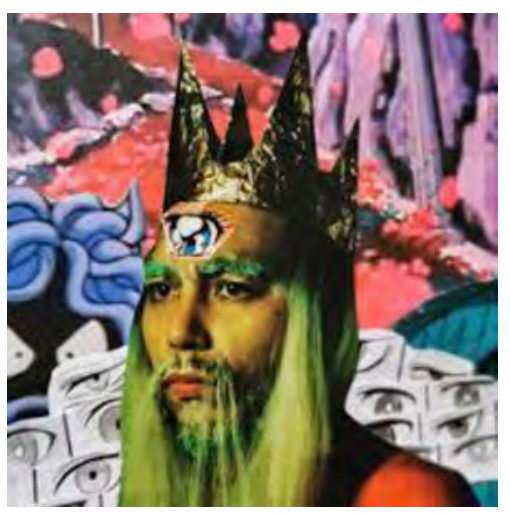

«Lo importante» (2020).

Estas nuevas canciones hablan de eso, de ponerse en pie y seguir luchando por algo sin que este contexto te destruya. Los temas apuntan a esas ideas, de que tú puedes lanzar una estaca a alguien en pos de un ideal pero hay gente súper real entre medio.

En enero de 2020 lanzaría lo que supone ser el adelanto de un nuevo disco que, en principio, recibirá el titulo de El sueño y que debería ver la luz a lo largo del año. Como adelanto del mismo presenta "Lo importante», canción producida por Max Munizaga y que de manera especular juega con las crisis en las relaciones personales, la imposibilidad para asumir el error, para salir de ese laberinto de dolor y volver a proseguir con fuerzas renovadas, valorando lo realmente «importante», parafraseando el título de la canción. La idea del autor es que la letra se entienda como una metáfora de la trágica situación que estaba viviendo Chile desde los últimos meses del año anterior, una manera de visibilizar el conflicto político y la ruptura social que sufrían sus compatriotas, apostando por el sentido de pertenencia, antes de que el covid-19 desbaratara todas las relaciones personales. Es así como conforma un tema desgarrador, confuso y lacerante, creado sobre una sutil base que recuerda al folclor andino cubierta por capas de electrónica indie y un fraseo que lo acerca al trap, delatando aún mas su proyección social.

Una canción tras otra, Sotomayor ha ido construyendo una obra que parece poner palabras a una generación. Los agradecimientos en las redes son constantes por parte de fans que se ven reflejados en sus historias, en sus reivindicaciones y en su singularidad. Sin duda, parafraseando a José Esteban Muñoz, es un artista de la vulnerabilidad, pues, como éste establece en su teoría sobre la Futuridad, las minorías tendrían una posibilidad a través de las estrategias estéticas para sobrevivir e imaginar maneras de ser dentro de los mundos utópicos (Alvarado, 2015: 104-110). Su concepto sobre la desidentificación propone que habría una tercera vía, llamémosla así, entre la identificación y la contraidentificación o el rechazo de identidades, y en ese nicho podríamos colocar al chileno como músico y artista. 
De esta forma resulta evidente que podría existir un grupo de espectadores queer que celebran y se reconocen en su obra a partir de poderse apropiar de su propuesta heterogénea, de su desafección de la norma y, en definitiva, de sus gestos de desafío social y sexual.

Estas reflexiones sobre (me llamo) Sebastián nos sirven para situar el proyecto de este artista, bastante desconocido en nuestro país, y desde ese punto poder profundizar en su capacidad por transformar sus canciones en imágenes, en ocasiones pregnantes y simbólicas; en otras, simples divertimentos, aunque a menudo con un horizonte vindicador nada complaciente que exhibe especialmente en los videoclips que ha podido realizar de sus sencillos más icónicos.

\section{PROYECTANDO IMÁGENES, CREANDO SIGNIFICADOS}

Decía Judith Butler (2007) que el género es performativo y que, por tanto, lo compondrían nuestras expresiones y nuestros comportamientos. Dicho de otra forma, si éste es lo que hacemos y el sexo lo que somos, ambos forman parte de lo que proyectamos. Por tanto, un artista debe hacer lo mismo cuando decide lanzar un determinado mensaje -no es cuestión únicamente de verbalizarlo, sino de convertirlo en extensión de su persona-.

Hemos utilizado repetidamente el término queer para referirnos al posicionamiento personal de Sotomayor, quien prefiere utilizar una palabra en español que se ajusta más a su realidad chilena y a su disidencia de género: «pensamiento de-generado» (Ocampo Cea, 2014). Pero ¿cuándo consideramos una imagen como tal? Según Barker y Scheele (2017):

Los momentos queer son aquellos que perturban la narrativa y desestabilizan la heteronormatividad, destacando aquello que es integral en ella en momentos que demuestran que el género es performativo, que las identidades no son fijas, o que las atracciones queer son posibles; o que transforman las interpretaciones binarias de sexualidad y género (103).

En el caso de los vídeos de (me llamo) Sebastián, esa performatividad, esa necesidad de mostrarse en su disidencia, se lleva a cabo desde la ironía y el humor, tanto como desde el dolor y la parodia, pues en algunos de ellos podemos rastrear cómo su pasado traumático se proyecta hacia el presente. Quizá, como teoriza Saidiya Hartman, todo ello le permita conectar con la vergüenza y con la culpa. Jack Halberstam mantiene también la misma opinión en su interesantísimo El arte queer del fracaso, retomando palabras de la anterior para recordarnos que cuando se exterioriza el conflicto en realidad lo que se consigue es una manera de superarlo y de olvidarlo (2011: 96).

Leandro Palencia (2008) aporta otros elementos a tener en cuenta cuando tratemos sobre audiovisual queer puesto que éste, de alguna forma, debe luchar contra una serie de estereotipos negativos que contribuyen a «la opresión, al prejuicio y la discriminación» que determinadas instituciones y costumbres entienden como 


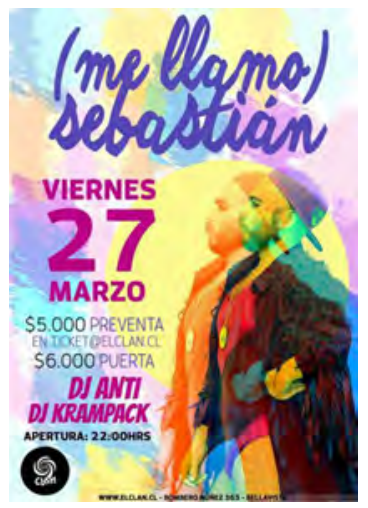

«superiores, necesarios e inmutables; sin los cuales considerarían que la vida es solo caos y vacío» (14-17).

Leandro Garrandés (2016: 18), por su parte, mantiene que una obra es queer «si, además de fluidificar sus contenidos y mostrar identidades resbaladizas (dentro y fuera del sexo) en conflicto, se deja intervenir, con naturalidad, por interrogantes acerca de lo queer».

El Oxford Dictionary of Film Studies nos aporta otra vía por la que abordar los trabajos de Sotomayor desde una perspectiva queer, pues entiende como tales aquellas performances y aquellas personas que «embody and celebrate pastiche, excess and camp, and demolish gender and sexual stereotypes», mientras que su obra debe mantener «its allegiance to sexual politics, cultural politics, and social change, continuing to offer both political and theoretical purchase for radical sexual communities» (2012: 341).

Desde este punto de vista, el homoerotismo que late en la mayoría de sus videoclips no es sino un elemento contagioso que actúa como pivote de su liberación personal. Es así como la identidad muta en «una construcción social que debe entenderse como un proceso abierto a constantes transformaciones y redefiniciones" (Córdoba, 2012: pos 798), mientras sus relatos audiovisuales le sirven para construir estereotipos, subjetividades y una ética personal alejada de la heteronormatividad, como resulta ser siempre su expresión de género.

Se trata de deconstruirse y de derribar prejuicios. Se trata también de ponerse «creativos para inventar otras masculinidades [...] y diseñar nuevas estrategias para liberarse del patriarcado y aprender a quererse sin miedos, sin relaciones de poder, sin abuso y sin violencia» (Herrera, 2019: 20).

Si habíamos visto cómo sus letras resultaban un atractivo indiscutible de su trabajo, resulta aún mucho más empática su presencia física, tanto sobre los escenarios como en la pantalla. Su imagen, descuidada y errática en ocasiones, perfectamente pensada en otras, forma parte de su posicionamiento sobre el género.

Nunca he tenido un productor que me asesore en cuanto a mi imagen. Yo me visto como quiero... siento que puedo cambiar cuando quiera. Más allá de cómo me visto 
o cómo ando, transmito en el arte de los discos, los vídeos y todo eso genera una correlación que tiene que ver con mi forma de ver la vida y profundizar el mensaje de la música que hago. La música me pedía cambios. Para mí es demasiado importante que cuestionemos el género en general, como que nosotros nacemos con un pene o una vagina y somos hombre y mujeres y, por eso, hay todo un código de vestimenta, código emocional y de ética. Yo creo en verdad que eso es una mentira, es una invención (Santa Cruz, 2016).

Esta libertad a la hora de no colocarse etiquetas nos permite entender que en cada proyecto su música, sus letras y su imagen forman parte de una deliberada propuesta personal, aunque reniegue de asesoramiento e incluso de intencionalidad. Todo ello parece más una estrategia comunicativa, a pesar de que pueda resultar fluir de una manera natural.

Esta cuestión resulta aún más paradójica cuando aclara que algunas de las ideas de sus videoclips parten de miembros de su equipo o de los propios realizadores de los mismos, por mucho que pudieran verse condicionados por la escasez de presupuesto en su ejecución. Además, ninguno de ellos parece aferrarse a los modelos tradicionales de la subcultura gay contemporánea -nos referimos, siguiendo a Leandro Palencia, a ese proceso de masculinización de los cuerpos que «más que desafiar ha reafirmado la virilidad normativa heterosexual» (2008: 30)-.

Sotomayor, en cambio, prefiere turbar las conciencias, apuntalando una debilidad que transforma en empoderamiento y que no teme al fracaso. Así, carente de vergüenza y de complejos, prefiere bordear lo absurdo, lo ridículo, ofreciéndose frívolo e irrelevante en más de una ocasión, para que leamos entre líneas el verdadero sentido de las imágenes. Es, por tanto, el suyo un discurso alternativo que trabaja desde el punto de vista de la cultura popular, además de sobre la identidad y el género, en paralelo con lo que Halberstam denomina la Baja Teoría y muy cerca de lo que se ha dado en bautizar como artistas de la vulnerabilidad (Muñoz, 2006).

A pesar de que en la actualidad y desde el Feminismo se haya criticado la Teoría Queer, ya que al «reducir la categoría mujer a una identidad puramente ideal niega toda base material sobre la que se construye la dominación sobre la parte femenina de la humanidad» (Zadú, 2009) -recordemos, además, que Judith Butler había cuestionado la identidad «mujer» de un feminismo que criticaba, al considerarlo heterosexista, pues excluía otras-, es evidente que lo queer en su intento de disolver todas las identidades oprimidas (o de crear algunas nuevas en las que sentirse como tal) ofrece un claro carácter reaccionario frente a la lucha por la emancipación de la mujer en nuestra sociedad patriarcal. Contrariamente a ello los planteamientos del cantante chileno se muestran conciliadores, tratando de derribar muchos de los prejuicios sociales y de las identidades de género tradicionales, en su caso especialmente las masculinas. Sotomayor revierte y cuestiona la virilidad, incluso se burla de ella pero sin caer nunca en el negging .

\footnotetext{
${ }^{4}$ Este término recién acuñado consiste en subrayar los «defectos» de una persona para aumentar su sentimiento de vulnerabilidad.
} 

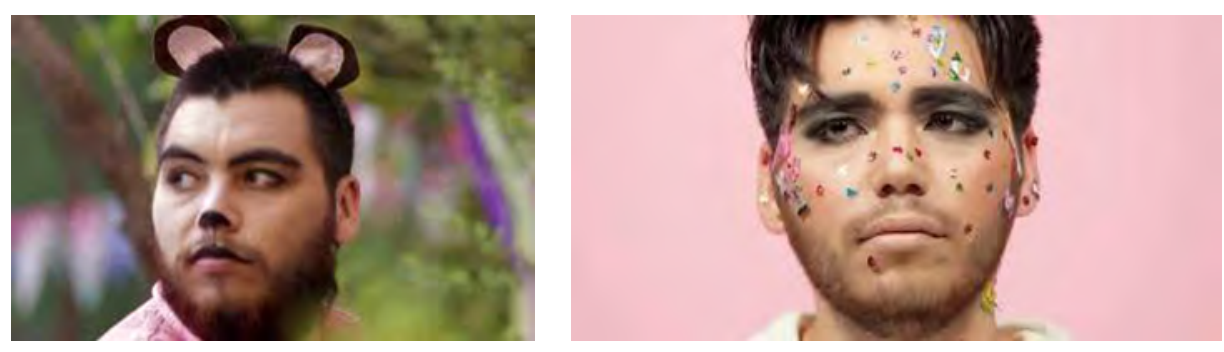

Fotogramas de «Varita mágica» y «Niños rosados».

De hecho, en el clip de "La fiesta», que reconoce su preferido al ser una idea $100 \%$ suya, admite que su imagen y el concepto le quedó «super chistoso», «hasta da pena-vergüenza- verlo, pero me encanta», llegaría a confesar, confirmando esa reversión de la virilidad masculina de la que hablábamos más arriba (Legorreta, 2015).

Entrevistado sobre el fundamento estético de sus vídeos no duda en reconocer que el punto en común es que tienen que ver con el juego, con hacer algo entretenido para enriquecer así el mensaje de la canción.

Aunque para realizar este trabajo hayamos escogido su producción oficial, la de sus trabajos más significativos, en este momento en el que la existencia se demuestra en las redes sociales, Sotomayor sube constantemente grabaciones caseras, tomas improvisadas, fragmentos de conciertos o entrevistas, con la idea de que su presencia y su mensaje sean constantes en internet, incluso durante los meses duros del confinamiento por el covid-19.

Sea como fuere, en la mayoría de ellos aborda, de una forma u otra, el tema de la desigualdad, incidiendo en cómo lo personal acaba resultando siempre político. Es así cómo, en algunos de sus planteamientos sobre el audiovisual, con su capacidad socializadora, ayuda a construir otros «estereotipos, subjetividades, imaginarios e incluso valores morales» (Dolera, 2018: 238).

Quizá el vídeo de «Varita mágica», dirigido por Jean Vargas en 2014, sea un buen ejemplo de ello, pues se cuestiona, a la par que la letra de la canción, el daño que la sociedad provoca al inculcarnos de pequeños la idea del amor romántico como el único y verdadero amor, como la más natural aspiración y el motor del ser humano. Sotomayor abordaba el tema en una entrevista (Jones, 2014) ahondando en que en la naturaleza no existe ese comportamiento tan «antinatural», no siendo necesaria esa experiencia para ser feliz. De ahí el guiño a la «animalización» de los protagonistas del clip, que parecen jugar con una libertad sexual que rompe la heteronormatividad para presentarnos parejas del mismo sexo en un ambiente cálido donde todos encuentran a su media naranja excepto nuestro protagonista, que, en soledad, espera un milagro que nunca llega, como sucede en la vida real. De nuevo, el mundo se reduce a una estructura patriarcal en la que el vulnerable y el diferente no encuentran su lugar. 


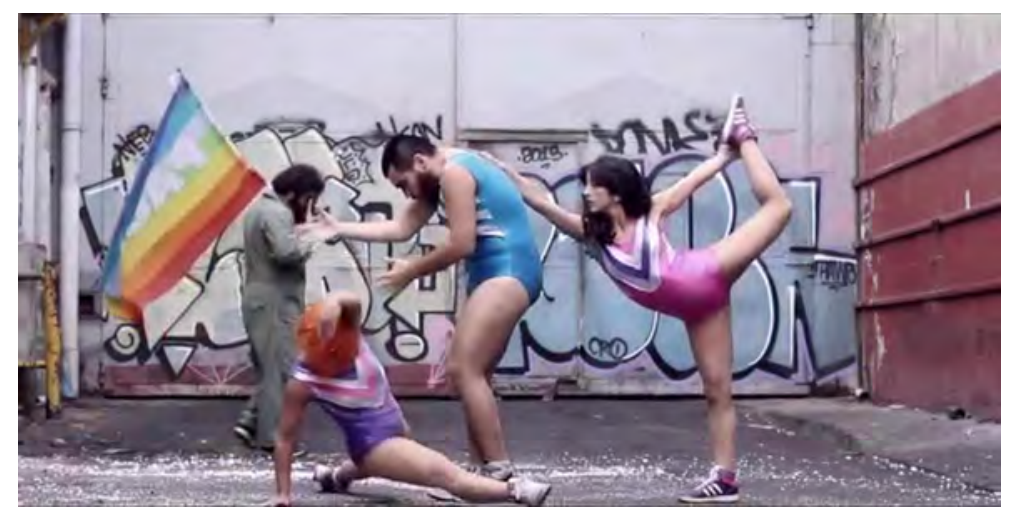

Fotograma de «La fiesta».

Pero no solo Disney y sus falsos estereotipos son el enemigo, sino que apuesta constantemente por el cambio de roles. Ejemplo de ello es, especialmente, el clip de "Niños rosados», firmado por Víctor Almendra con dirección artística de Mara Solís de Ovando. En él juega con imágenes que reflexionan sobre los cambios que la adolescencia provoca en quienes apenas descubren su sexualidad y su identidad de género, y donde los roles son una imposición y no una expresión de ésta, como realmente debería ser. Sebastián narra esas tensiones en primera persona mostrándonos su propia visión de un proceso lleno de inseguridades con imágenes arquetípicas de la vida donde la confusión, el crecimiento y el dolor suelen ir de la mano, dejando claro que «no tiene que haber una actividad social (asociada) a un género o a tener un pene o una vagina. No tiene sentido" (Jones, 2014), lo que en el feminismo se denomina abolición del género. Sin duda, vídeo y canción son también una reflexión sobre la niñez trans, si lo abordamos desde el título, aunque el footage de imágenes del clip resulte mucho mas filogay.

Si estos dos clips, aparecidos el mismo año, pivotaban sobre conceptos bastante claros, tres ańos antes el proyecto se daba a conocer con el firmado por Roberto Doveris y Víctor Almendra para «Venir». La canción, un primer himno confesional sobre la libertad de elección en la vida, está interpretada por un grupo de chicos y chicas en una versión parcialmente karaoke mientras el protagonista se dirige a la cámara para subrayar las frases más lapidarias del texto: «Considera que los miedos son los mismos para todos, pero cada uno debe escoger. Si quieres yo te acompaño para ver que te quedes tranquilo hasta que lo entiendas». Si las imágenes cotidianas del clip no invitan a una lectura radical de lo que se nos cuenta, la insistencia del cantante convierte el recitado en una letanía que nos recuerda lo esencial: defender la diversidad y entender el mensaje bajo una interpretación poética que plantea un código ético y emocional que reconstruye y derriba prejuicios sobre el género.

En «La fiesta», Jorge Candía y Valentina Oyarzum daban alas a la filosofía body positive, en un clip en el que un Sotomayor en mallas baila desinhibido junto 


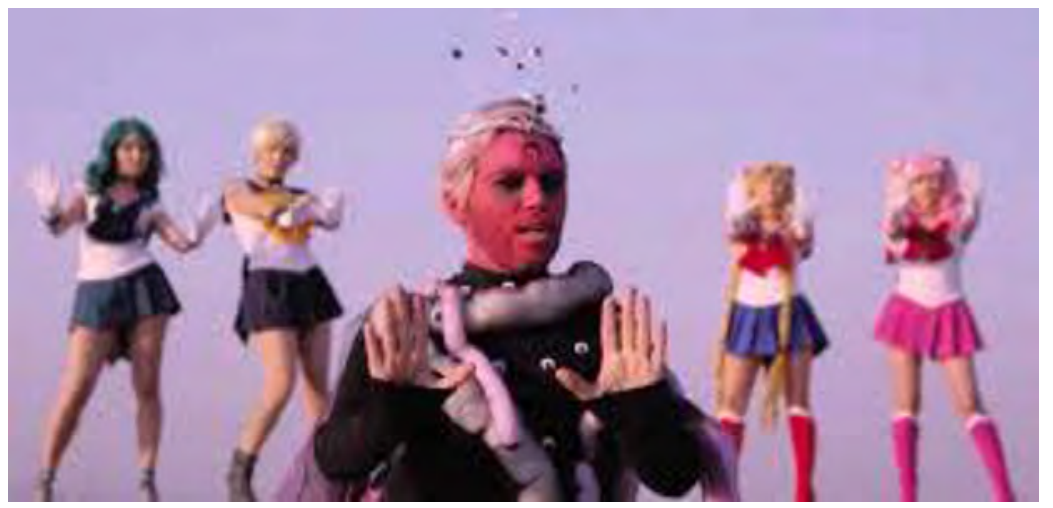

Fotograma de $<3$ (Corazón).

a Diana Carvajal, Francisca Tapia y Christine San Martín, que le acompañan. Una coreografía «bizarra» y desacomplejada, teatral y arrabalera, en medio de un callejón sucio, solitario y lleno de grafitis, sirve para recordar al mundo que realmente la fiesta siempre está dentro de cada uno de nosotros. Una reivindicativa bandera multicolor con la palabra "PACE» ondea en la performance y nos ubica en el lugar al que realmente pertenecen el pequeño grupo de outsiders. La mirada confidente es absolutamente queer eye, libre de referentes patriarcales y nacida a partir de la propia aceptación. El vídeo es probablemente de los más sencillos pero efectivos de toda su producción, directo a nuestra inteligencia emocional.

Este carácter lúdico lo explota en otros tantos clips, tengan o no relación directa con el carácter reivindicativo de sus textos, aunque siempre saliendo de lo que Beatriz Preciado denomina como el gueto hetero, consciente de que ser gay es vivir permanentemente en zona de guerra porque «el precio de la visibilidad es una constante amenaza de violencia» (Sáez, 2012: pos. 1083).

En "<3 (Corazón)», primer single de La belleza, Sebastián se divierte en su particular homenaje al Manga mientras grita: «No, no, no, no. Nadie nos ordene cómo vivir el amor». De nuevo, Víctor Almendra se encarga de esta disparatada performance en la que el cantante y sus chicas aparecen con los cosplay de Sailor Moon, la famosa serie de Naoko Takeuchi, popular tanto por su carácter sentai como por las «mahōi shōjo», las típicas adolescentes niponas que poseen algún poder mágicos.

En el texto que lo acompaña en YouTube se presenta así (suponemos escrito por el propio artista):

5 Agradezco a Paloma Gómez Pereira, joven historiadora del arte, sus conocimientos de anime y manga, así como sus interpretaciones sobre algunas imágenes de los clips del artista. 


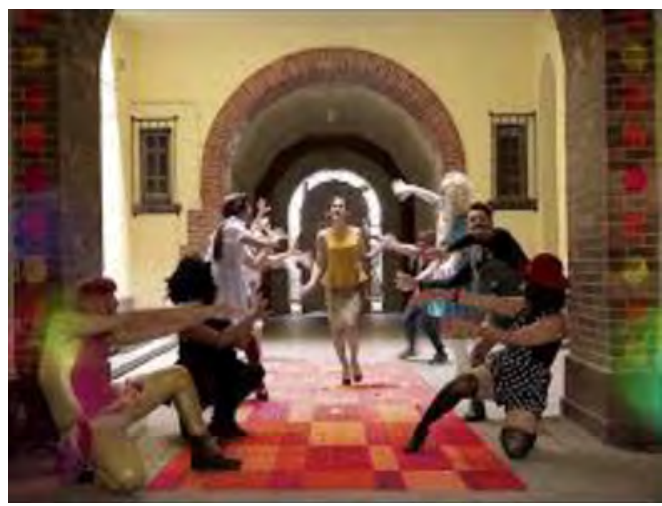

Victoria Volkóva en la coreo final de «Hormonas».

Sebastián interpreta al terrible sistema al que estamos sometidos día a día, encarnado en un ser maligno y homosexual (obviamente). Con miles de ojos y cientos de tentáculos se presenta listo para vigilarnos, estrangularnos y decirnos ${ }_{i} \mathrm{NO}$ ! al más mínimo asomo de diversidad. El monstruo-sistema quiere que siempre vivamos igual sin cuestionarnos las estructuras impuestas y siguiendo la línea que él mismo nos traza. Para nuestra suerte, una agrupación de heroínas asiáticas (que no tienen nada que ver con ningún otro grupo de heroínas asiáticas, por asuntos legales) está decidida, con el poder del amor, a transformar a este villano en pura bondad; dulzura infinita -tal como es el (me llamo) Sebastián en la realidad-. ¿Lograrán su cometido? (https://youtu.be/BJofUzxUJhI).

Como no podía ser de otra manera, el «virus» acaba vencido, vomitando toda la inquina, todo el mal, mientras el amor y la diversidad triunfan. Muy simple, muy obvio, pero de nuevo muy efectivo.

Ese mismo 2015, aunque grabado el año anterior, también subiría a las redes «Hormonas», obra de Benjy Estrada para el colectivo audiovisual mexicano Los niños perdidos. El clip está protagonizado por Victoria Volkóva, mujer trans famosa por haber compartido su proceso en YouTube, lo que la convertiría en referente de la comunidad LGTBI+ en el país azteca, así como en influencer, abriéndole las puertas para sus posteriores trabajos como actriz.

La canción y el clip plantean no solo la necesaria ingesta de hormonas de la protagonista, sino los obstáculos de una relación romántica cuando contar algo tan íntimo, tu transición, a un desconocido te parece en principio absolutamente innecesario. De alguna forma personifica la lucha entre dar rienda suelta a los sentimientos o bien controlar las emociones, un proceso para el que se necesita deconstruirse y acabar con lo que hasta ahora conocemos como los estereotipos de género.

El vídeo nos muestra un problema común entre el colectivo trans, pero lo hace desde una óptica que arrincona los complejos y que termina en una explo- 


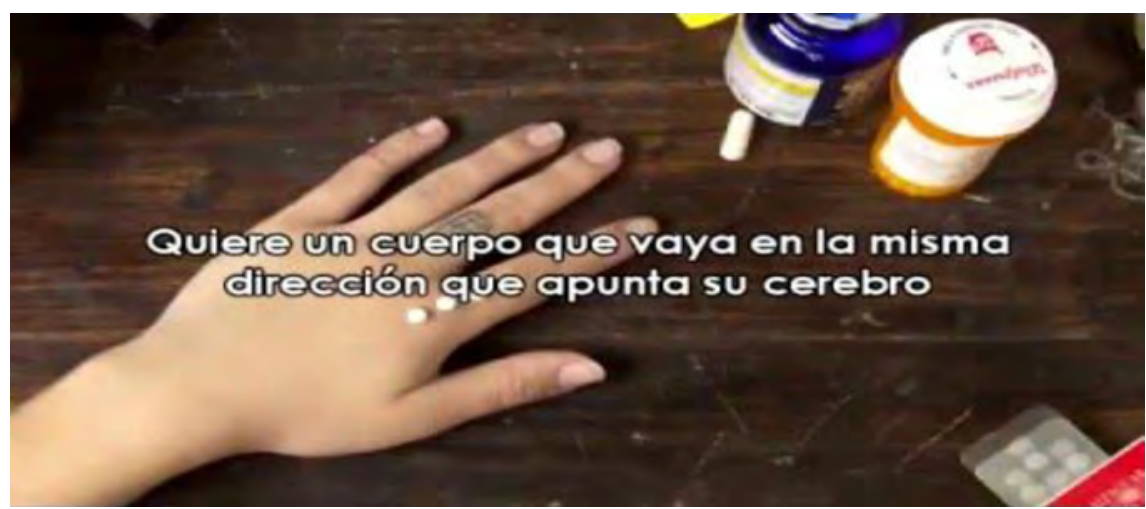

sión de optimismo, con una nueva coreo final en la que Sebastián, junto con otros jóvenes, danza disfrazado alrededor de la chica. Otra vez el mensaje resulta esperanzador, positivo y, lo que es más importante, útil entre la evidente subversión y la parodia final.

Es así como sigue explorando el melodrama desde la capacidad para convertir los momentos más amargos de la vida en experiencias que determinan quiénes seremos en el futuro. Su discurso, aun desde el humor, siempre subyace político.

Sobre la canción declararía un par de años más tarde, en una entrevista realizada por Constanza Rifo para PICNIC (2017) -recogida por el magazín chileno $P O T Q-$ : «Encuentro demasiado ridículo que exista gente trans y que no hayan leyes para cuidarlos. Es vergonzoso. Y si yo desde mi lugar como cantante puedo hablar algo de lo que la gente no puede decir nada, obvio que lo voy a decir», apuntando que la había compuesto para Daniela Vega mucho antes de que fuera mundialmente conocida tras protagonizar la oscarizada Una mujer fantástica, de Sebastián Lelio.

Este vídeo y esta canción parecen suponer un punto de inflexión hacia nuevos territorios de una mayor introspección personal, como declararía en la misma entrevista:

Siento que también me di permiso para eso, porque mis primeros discos son dulces, tiernos, chistosos, para caer bien. Yo creo que ese ingrediente chistoso se ha ido desvaneciendo a medida que los discos pasan, me siento con más permiso y seguridad de que ya no me importa agradar. Sé que hay gente que me apaña, que escucha la hueá y le gusta, y no porque es chistoso, sino porque ven una cosa que es media pesimista, al final.

"Final de temporada» y el lyric video de "Baila como hombre» parecen sugerir ese cambio. El primero, obra de Nicolás Montenegro para ChocoChips Lab, está compuesto por stock film footage de clásicos americanos en blanco y negro que nos muestran una sucesión de parejas que ilustran una gran historia de desamor que cierra así: «La temporada de los dos fueron capítulos perfectos que no me cansaría 


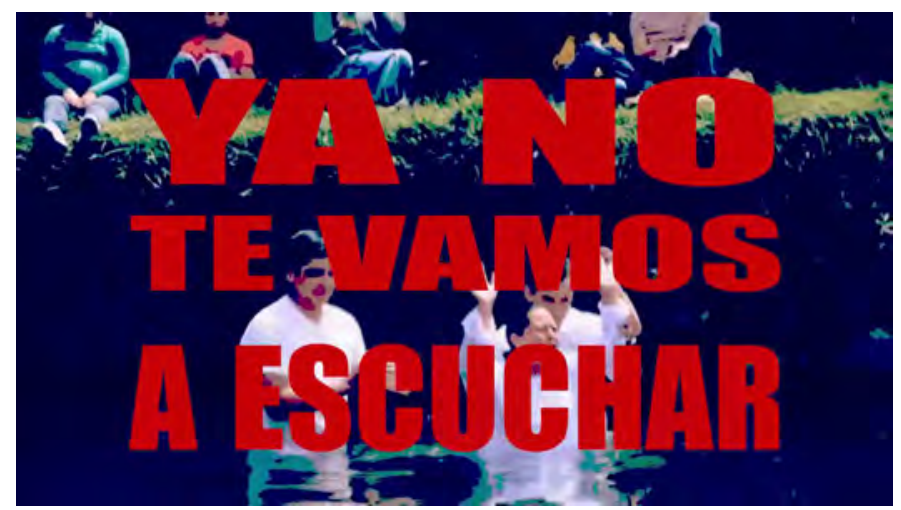

Imagen del lyric video de «Baila como hombre».

de volver a ver [...]. Dudo que exista en el futuro alguna otra serie que nos pueda superar». Triste y emotivo.

El lyric, firmado por la misma productora, propone un sencillo ejercicio audiovisual en el que se subraya la labor castradora de la religión. Usa imágenes paródicas aceleradas, que suele repetir e intercalar con otras del propio artista cantando "travestido" con distintos motivos, para un mensaje muy serio que centra su atención en la crítica a los vociferantes predicadores evangélicos, tan abundantes en la América Latina, y sus falsos sanadores que convierten la homosexualidad en una enfermedad -recordemos que la OMS dejó de hacerlo en 1990-que puede ser «revertida» gracias a diferentes terapias. No podemos olvidar que Dilma Rouseff, hace apenas cinco años, siendo presidenta de Brasil intentó en varias ocasiones aprobar una ley contra la homofobia, que fue constante y sistemáticamente evitada gracias a los grupos más conservadores, muchos de ellos miembros activos o afines de las diferentes iglesias evangélicas que "gobiernan» el país. Es por ello por lo que no se trata de un lyric video al uso, sino de un ejemplo de coherencia y de posicionamiento político.

Ya adelantábamos en el epígrafe anterior cómo, un año más tarde, en 2016 y en homenaje a Daniel Zamudio, Valentina Andrade y Guillermo Pastenes filmaban un lipdub de la misma canción para dejar en la memoria colectiva el cobarde asesinato homófobo en el parque San Borja de Santiago de Chile. Sebastián, las Vulvas furiosas y un pequeño grupo de personas que parece pasaban por allí se ven envueltos en lo que parece una espontánea coreografía que termina en la placa que conmemora el suceso y que subraya el mensaje de la canción original: libertad de elección y justicia social. El propio autor nos dejaría en los textos que lo acompañan en su edición en YouTube este mensaje: «Sé absolutamente que hacer un video ridículo no cambia en nada las injusticias de este país, pero si logramos poner una pregunta abierta en la cabeza de alguien, nos sentimos pagados. ¿Nos puedes ayudar a difundir este video?» (https://youtu.be/zRGH6WtNci8). 


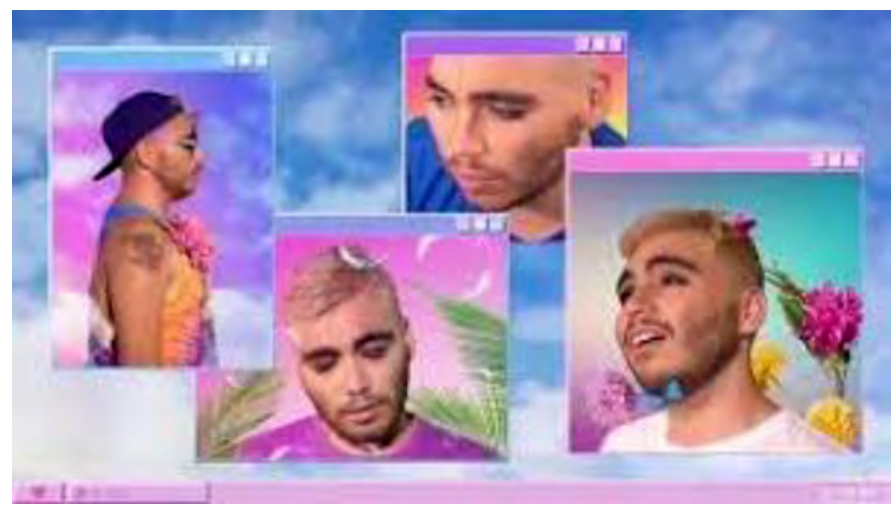

(me llamo) Sebastián dentro del juego de «Sol, cuídate».

Ésta fue quizá su última concesión a ese lado «lúdico» con el que ayudaba a difundir el drama. Toda la producción audiovisual que vendría a continuación abandonaría estas formas para buscar un camino mucho más introspectivo en consonancia con la deriva emocional de las letras de sus canciones. «Sol, cuídate» o «Las polillas» fueron un buen ejemplo de ello.

La primera, una hermosa balada sobre el fin del amor, en la que Sebastián utiliza el sobrepeso como eje de la desafección, en un vídeo de clara latencia homosexual a base de cronofotografía, $\mathrm{NPC}^{6}$ y multipantalla, como si estuviésemos dentro de una ampliación de los SIMS, que propone mostrarnos a dos chicos que podemos «caracterizar» a voluntad. Parece un juego poliédrico entre lo que vemos y lo que escuchamos: «Me miras fijo, beso de amigos. $\mathrm{Y}$ antes de irte bien voladito me dices ¡Cuídate, sol, cuídate! Si me cuidara ya no te abriría más mi puerta, te eliminaría de todas mis cuentas». Con dirección de arte de Roberto Riveros y Marita Aravena y realizado por MILKY!, resulta uno de sus clips más creativos, que no despeja la duda de si acabamos de ver un "game over", como aparece en el fade out final, o simplemente un punto y seguido.

Este vértigo emocional, cada vez más privado de artificio, culmina en el audiovisual de "Las polillas», obra de Bernardo Quesney. La idea es sencilla, despojarse de todo lo superfluo, como había propuesto Cristian Heyne con la música y el mensaje del artista chileno, en una idea original de Miau Miau y del propio cantante. Sebastián se encierra en una nave desnuda, dedica el vídeo al fracaso en la entrega personal, siempre infinita, nunca suficiente, e interpreta una danza contemporánea ataviado únicamente con una sudadera gris que apenas destaca en la fotografía contrastada pero tenue de Matías Illanes. Se hace rodear de un grupo de bailarines

\footnotetext{
${ }^{6}$ Non-player character.
} 


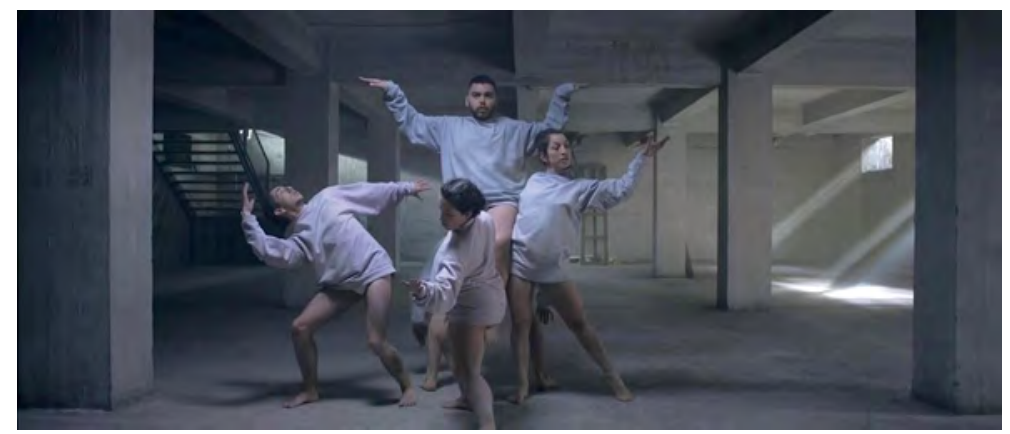

Imagen final de «Las polillas».

y de las Vulvas furiosas, que parecen violentarlo y adorarlo al mismo tiempo, mientras él es incapaz de escapar de "su propia cabeza», como la polilla del título, mientras intenta salir (entender) ese círculo de destrucción personal que supone sentir el desafecto como constante emocional en las relaciones personales.

Cuestiones como la incomprensión, el encierro, la desnudez o la intensidad emocional empezarán a ser una constante visual en sus obras posteriores, incluso parecerá que las pulsiones sexuales transmutarán en un elemento perturbador en la expresión del propio artista, en su propia entrega.

Todo ello sigue siendo profundamente autobiográfico. De este clip diría que había nacido de la necesidad de rendir y tener éxito, «ser suficiente para una pareja, para unos fans que te piden unas fotos... y uno a veces sólo está intentando hacerlo lo mejor que puede [...] tenemos las mejores intenciones pero a [la] otra persona le parece que se hizo todo mal. Y eso se puede pasar también en un ámbito político e intelectual» (Littlebab, 2016).

La última colaboración con Heyne, «Hijos del peligro», será su trabajo más conocido hasta la fecha, superando el millón de visualizaciones en YouTube, lo que es un gran logro para un artista bastante minoritario y que trabaja casi siempre desde la autogestión. En este caso volvería a contar con Roberto Doveris para ilustrar una historia en la cual el amor y la muerte van de la mano. El sobrecogedor videoclip planteará una relato en paralelo al mensaje de la canción, que planea sobre el amor y la amenaza del sida.

Quiero creer que hay cosas que son para siempre. Que a pesar de las enfermedades mortales, de las personas que quieren rompernos por nuestra diferencia, de los abusos que recibimos todo los días... existen lazos que nos sostienen. Materia que permanecerá, momentos por los que vale la pena morir. Instantes sin miedo de puro amor (P.R., 2016).

Esta dupla se nos muestra en imágenes a través de una historia, que resulta simultánea, en la que dos chicos parece que en su rutina diaria cruzan miradas, se 

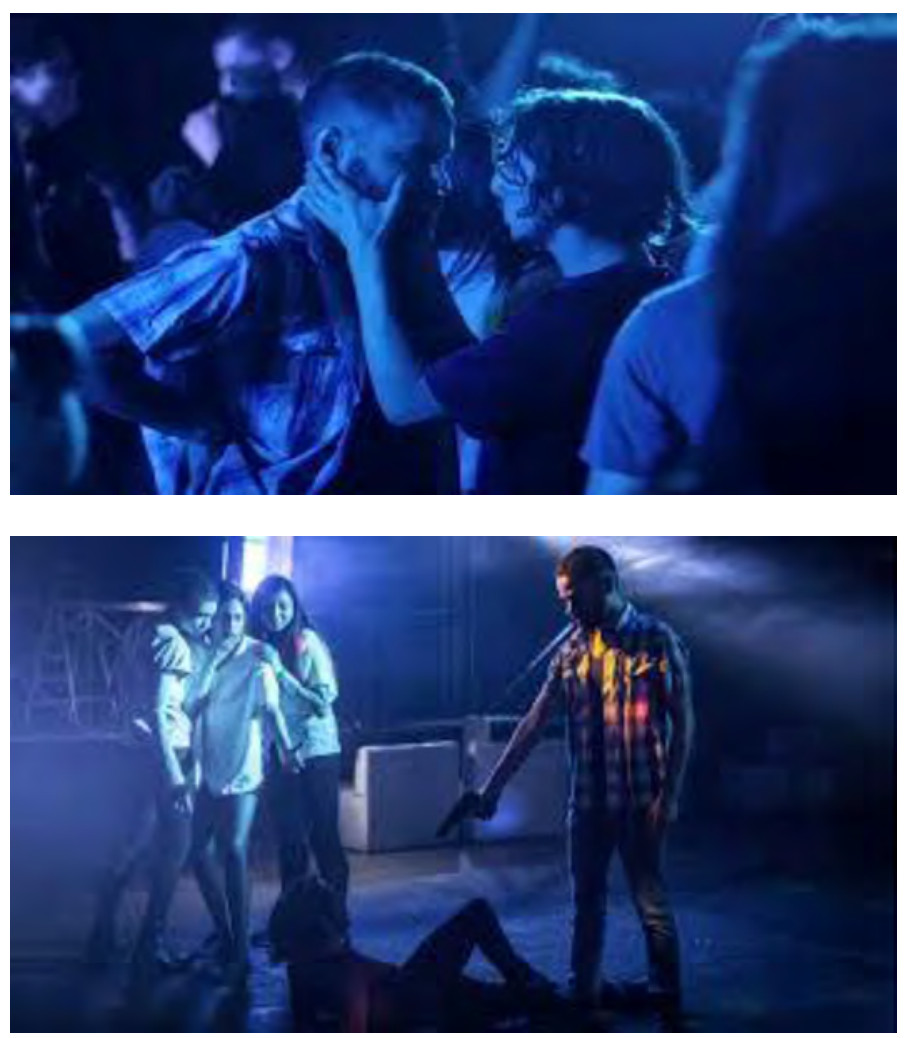

Imágenes del tiroteo en «Hijos del peligro».

atraen, para más tarde encontrarse en la pista de baile. Se acercan y cuando va a estallar una tensión sexual evidente en realidad uno dispara al otro dando comienzo a un tiroteo indiscriminado, pero mientras esto sucede exhalan un último acto de amor, un apasionado beso.

Parece una metáfora extrema sobre la pasión y el deseo, pero solo lo parece, pues no deja de ser un atentado homofóbico, como hemos visto tantas veces en los últimos años (incluyendo los trans y lesbofóbicos). Solo en Chile, en 2018, hubo casi 700 denuncias por violencia y abusos basadas en la orientación sexual o la identidad de género, aunque en este caso sea un homenaje a los que dejaron su vida en el tiroteo de Orlando ${ }^{7}$, a las muertes a manos del odio machista hacia la diversidad

7 Nos referimos al tiroteo en la discoteca gay Pulse, en Orlando, el 12 de junio de 2016, en el que murieron cinco personas y otras tantas resultaron heridas. El autor, Omar Mir Seddique Mateen, había jurado lealtad al Estado Islámico, grupo que terminaría asumiendo su autoría. 


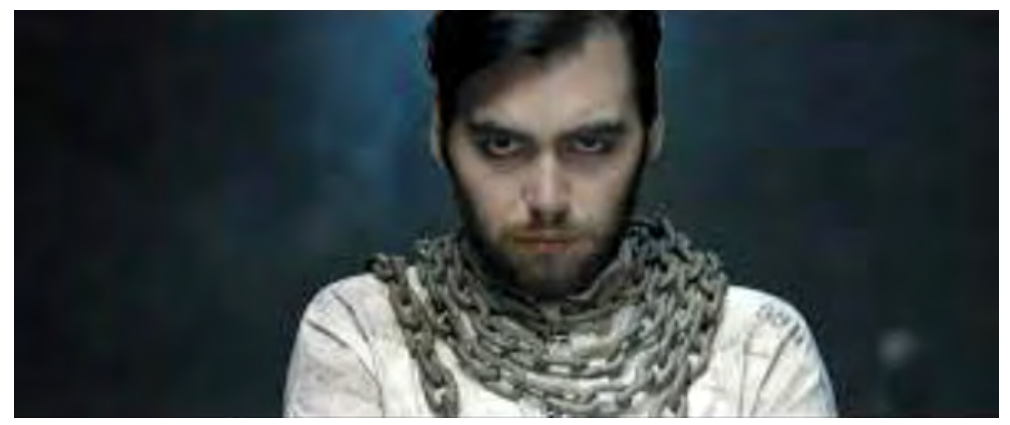

sexual. Es así como transforma la canción en un manifiesto, una denuncia, una tragedia que perdura en la memoria de quienes la ven, especialmente en el colectivo LGTBI+. Sebastián nos recuerda con ello que la disidencia es un riesgo; como mantiene Coral Herrera, si el feminismo no ha matado a nadie, «el machismo lo hace todos los días» (2019: 14).

En una entrevista a NOISEY siente la necesidad de subrayar las imágenes que cierran el clip, mientras lo dedica a aquéllos que «han sido marcados»:

Siento que esos besos son la verdadera y única respuesta a la violencia. Ante las balas y la catástrofe respondemos con amor, amor por los caídos y amor incluso por ese que te está disparando. No sé, creo que si algo le podemos enseñar al mundo de hoy es aprender a amar [...]. Roberto es la persona que hizo mi primer videoclip [...] yo le conté la idea y le encantó. Además le di la responsabilidad de que lo rodara mientras yo me encontraba girando por las Europas (Ocampo y Ocampo, 2016).

Revisando en varias ocasiones este material nos vienen a la cabeza las palabras de Garrandés cuando establece cómo el deseo coloca al sujeto deseado en una situación «de subjetividad my anómala (pues) transformado en delirio y alojado en una estancia cerrada [...] puede causar espejismos atroces» (2016: 36). De alguna forma, esta lectura también se nos antoja plausible.

Tras cerrar la colaboración musical con Heyne y embarcarse en una nueva etapa creativa durante la grabación de "La sombra», reorienta toda su obra. Como diría G. Martín, «el movimiento genera cambio y el cambio supone algún tipo de pérdida, algo que se queda atrás. Aunque sea la pérdida de esa apacibilidad tan propia del que vive en la inercia» (2016: pos. 6532). Será el comienzo del abandono al pesimismo más absoluto, marcado por nuevas experiencias personales, entre ellas la enfermedad, y de abrazar otras influencias estéticas que dejaban atrás al Sebastián con necesidad de agradar y de ser aceptado de los discos anteriores.

Este cambio en su definición estética vendrá de la mano de Felipe Reuters de la Maza y Francisca Correa, encargados de poner en imágenes el primer single del disco, "Edificios», una canción que habla sobre la fragilidad de la belleza efímera, de los romances que sabemos condenados al fracaso, de liberarse de aquello que asfixia nuestra propia existencia, aunque dependamos de ello. 


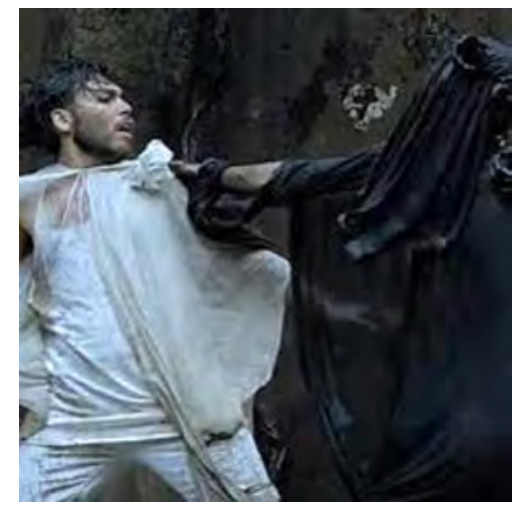

La lucha contra «la sombra» en «Edificios».

El propio músico abordaría este enfrentamiento inspirándose en la serie Buffy, Cazavampiros (Buffy, The Vampire Slayer, 1997-2003), de la que en diversas ocasiones se declararía fan confeso. El éxito de ésta derivaría, como llegó a afirmar su productor ejecutivo, Joss Whedon, en el cuidado que ponían en los guiones para ser emocional, política y filosóficamente significativos, en un intento de trascender la mera cultura pop. Para Sotomayor la serie «describe la transformación de aquellos personajes que fueron muy buenos, pero que por muchos motivos se aferran al dolor y lo toman para convertirlo en éxtasis de poder, trasformándolos en una sombra de sus antiguos seres» (Valencia, 2017). Y, obviamente, la sombra lo engulle todo.

«Dedicado a los que vivimos en el éxtasis a pesar de la condena» arranca un clip con un Sebastián homenajeando a Buffy, con los ojos pintados de negro, como los personajes de la serie cuya magia se convertía en una fuente poderosa que les permitía enfrentarse a cualquier cosa. Magia como poder que va a proporcionar al cantante, encadenado en la imagen, el valor para enfrentarse y vencer a la sombra que lo aterra, rodeado de jóvenes con los ojos vendados, que se acaban también liberando, en una utopía desgarradora que dejará sus cicatrices marcadas en el rostro.

El impacto limitado del disco, junto con los problemas que finalmente le llevarían a tomar la decisión de dejar Chile, pudieron ser las causas por la que abandonara la posibilidad de hacer otros clips del LP.

Una nueva etapa parece comenzar con la edición de un EP con tres canciones en colaboración con Martín Berrios y Max Munizaga. La primera de ellas, «El valor", sale como adelanto del proyecto audiovisual, encargando un lyric video de animación a Diego Lomelín de inspiración en el anime de Sailor Moon. Según sus propias palabras, quería resumir las emociones que habían inundado su vida en los últimos meses: «Me gustaría dejar escrito que si uno tiene el poder para sentir miedo, tiene el mismo poder y capacidad para generar cualquier otra emoción dentro de ti mismo", pues es una obviedad que no se puede ser valiente sin antes haberlo sen- 


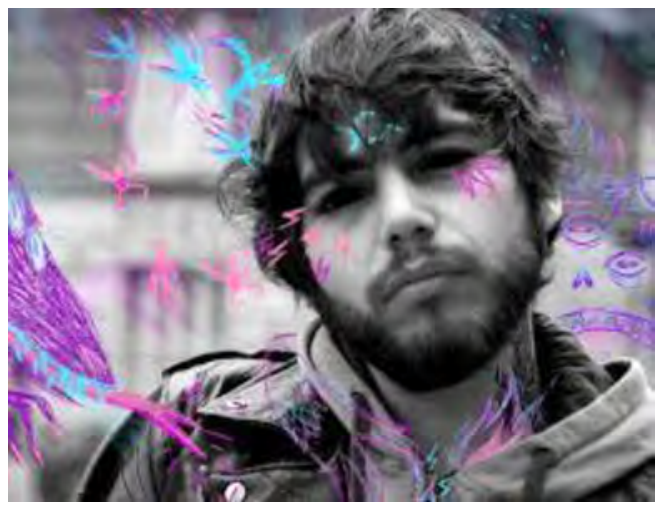

Imagen promocional para «Edificios».

tido. El clip acaba con una dedicatoria a aquéllos que «escogen convertir sus hilos en un tejido en vez de (en) una atadura».

Realmente, este adelanto servía para terminar el verdadero audiovisual que enlazaba los tres temas del EP y que titularía El dolor es un momento. El valor es la fogata, y que se publicaría en septiembre de 2018. Un clip de algo más de once minutos, fotografiado por Arnaldo Rodríguez y dirigido por el realizador Matias Bize (Premio Goya, en 2011, por La vida de los peces), en el que continuamos con un ejercicio de danza contemporáneo protagonizado por el artista chileno junto a sus inseparables Vulvas furiosas, Diana Carvajal y Francisca Tapia, de quienes partiría la idea de la triple coreografía en plano secuencia que bascula entre la claustrofóbica abstracción del dolor, pues todo se rueda en el interior de un apartamento vacío, y el viaje interior, que parece exorcizar los demonios con los que había tenido que convivir tras la denuncia a Pablo Gálvez Zúñiga y las acusaciones vertidas sobre su persona. Realmente el clip funciona como el cortometraje de una intensa travesía emocional que, al igual que había venido haciendo hasta ahora, tiene destinatarios concretos: «Dedicado al vacío que nos come y nos mueve». / "Dedicado al hilo que nos mantiene enredados». / "Dedicado a quienes creen que el amor es la respuesta.»

El vídeo comienza con "El dolor es un momento", donde el protagonista se entrega «poco a poco a las emociones de la letra de la misma canción; luego ya más desenvuelto, con más soltura en los movimientos y más participación de Diana Carvajal y Francisca Tapia [...], aparece la segunda canción 'El Valor', que nos muestra los hilos que nunca se quiebran y que van uniendo este plano secuencia; finalmente 'Es la fogata' la que cierra el ciclo de emociones con movimientos artísticos mucho más marcados y un arte que acompaña perfectamente a los estados (de ánimo) de los protagonistas» (Mundo Películas Tv, 2018).

Sin duda, entre 2011 y finales de 2018 habían cambiado completamente la situación personal de Sotomayor y la forma de comunicar sus experiencias vitales y sus posicionamientos políticos, tendiendo cada vez más hacia la abstracción de las 

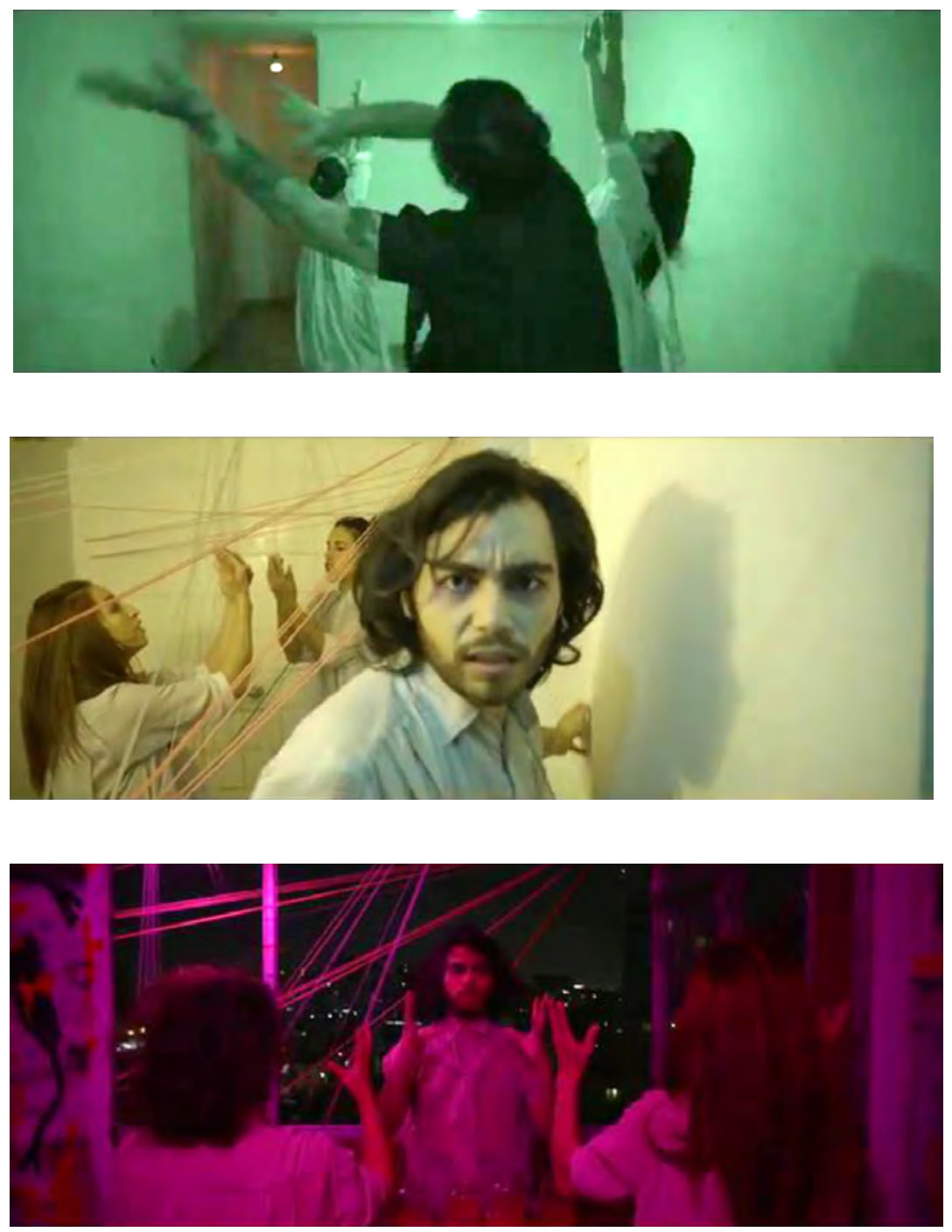

emociones, a una mayor introspección y a la necesaria interpretación por parte de quienes buscan en las imágenes el sentido del mensaje de la canción. El Sebastián desvergonzado y animoso de los comienzos se diluiría en el intenso y comprometido creador actual, evolución natural para alguien que llegaría a afirmar que «la persona realmente revolucionaria es la persona compasiva». El amor es lo único que trasciende, que diría Christopher Nolan. 
A pesar de ello, podemos seguir intuyendo que, por encima de trabajar sobre determinadas obsesiones personales, sigue habiendo un compromiso próximo a lo queer, especialmente cuando sus clips siguen examinando las relaciones de poder que subyacen a la categorización de determinadas identidades y de la denuncia de la opresión en los sistemas sociales que requieren una profunda transformación. En definitiva, hay un concienzudo trabajo sobre la importancia y la validez del discurso, y sobre los supuestos en los que éste descansa.

De hecho, la última de sus producciones audiovisuales, obra de Cristóbal León, ofrece nuevas estrategias para redefinir la lucha de siempre bajo el definitorio título de «Lo importante». Como ya habíamos apuntado con anterioridad, la canción no es más que una metáfora de la trágica situación vivida por Chile desde finales de 2019, dando voz a un conflicto político cada vez más lacerante que amenazaba con transformar a una vulnerable sociedad al borde de la ruptura precovid-19 - de ahí entendemos la base andina utilizada en la producción, así como su acercamiento al trap, como ya habíamos apuntado-.

El clip, en el que incluso se atreven con la stop-motion, comienza con el lamento de una viuda, sobre un fondo azul cielo en el que sube una columna de humo blanco, en el que pide «justicia social, piedad, que el gobierno les pague la pensión». La voz se apaga y sobreimpresa aparece la dedicatoria, más extensa que nunca:

Dedicado a quienes se entregan en la lucha de cumplir sus sueños.

Dedicado al ermitańo que paga con su soledad, el coste de la libertad.

Dedicado a los árboles dormidos que hoy despiertan de su letargo.

Dedicado a los que volvieron a encender la llama, a los que se atrevieron a comer el fruto que nos habían prohibido.

Dedicada a la danza de manos entrelazadas que se teje

bajo las bomba de humo que nos lanzan.

Sin sus ojos cerrados, no podríamos ver esta noche.

Nos vamos a encontrar una y otra vez.

A partir de ese momento comienza una danza-apareamiento entre dos chicos (el viajero: Sebastián Sotomayor, el roble: Rodolfo Robles) que mutan y parecen no entenderse. La historia no solo retrata cómo los buenos momentos de una relación se pierden sin darnos cuentan, por nimiedades, por obcecarse, por pequeños errores, sin ser capaces de mirar más allá y solucionarlo, sin darse cuenta de lo importante, sino que se transforma en metáfora del conflicto en mayúsculas.

Mientras la gente se empuja en las veredas

¡Qué tonto fui! Me quedé con la pelea

No supe quitar de encima la barrera

Por las cosas

Más triviales

Se me olvida

Lo importan

Lo importan

Lo importan

Lo importante 

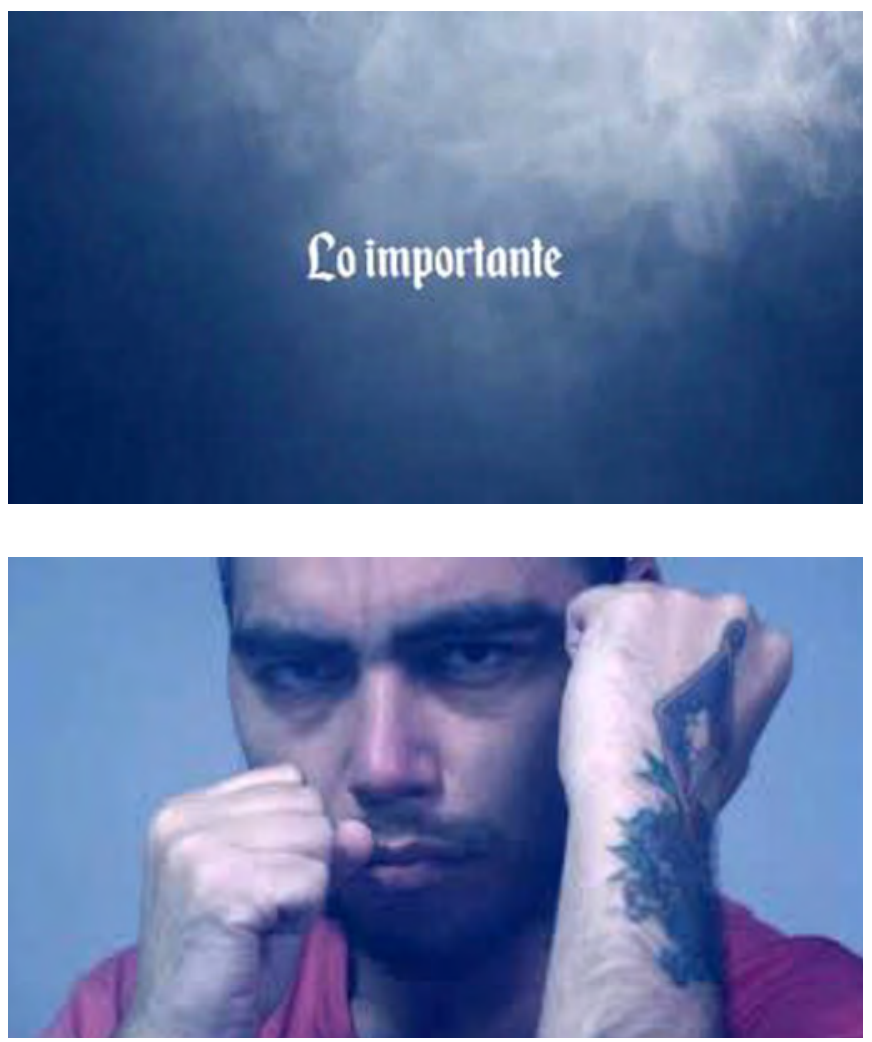

Las bombas de humo, la memoria y la lucha en «Lo Importante».

Como relato especular, el clip recuerda a los chilenos (y a quienes hemos sido conscientes de la situación que ha vivido el país) cuál es el camino. O como dice Fernando Bside (2020), nos obliga a «abrir de nuevo los ojos y tener una nueva perspectiva que vuelva a unirnos con más fuerza». El tercer ojo en la frente con el que ambos están caracterizados en el vídeo resulta claramente significativo.

Esta última obra nos muestra el apasionante proceso en el que se encuentra inmerso: en lo personal, en lo social, como artista y como activista frente al sistema. Por tanto, sus propuestas son siempre un mecanismo ideológico. Como el mismo confesaría en una entrevista: «Quiero que cuando me muera, porque todos nos vamos a morir, me gustaría que alguien pudiera acceder a esta música y encontrar como a un ser humano que se entregó por completo» (Valencia, 2017).

Necesariamente habrá que seguir reflexionando sobre su deriva emocional en el futuro y, en definitiva, ser testigos de cómo el viaje personal de (me llamo) Sebastián invita a replantearse la representación de lo queer en determinadas concepciones artísticas, pudiendo entenderse como un espacio liminar, un espacio en el 


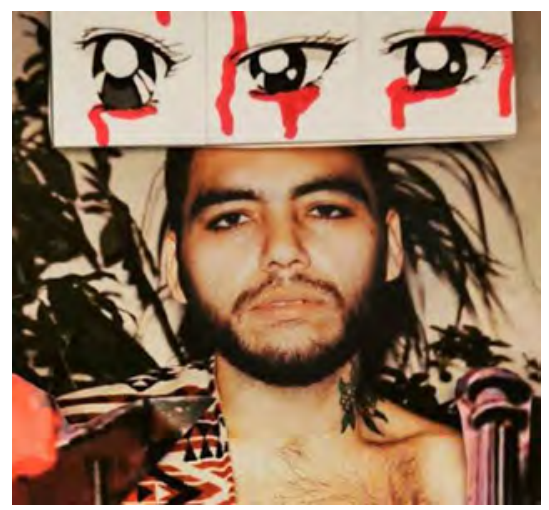

Para todos los que creen que llegará la era del amor. Foto: Diluvio.

cual las identidades se difuminan e incluso se abolen, y donde los modos de representación heteronormativos tienden a desaparecer hasta diluirse en la nada, convirtiendo su obra en un espacio de resiliencia.

RECIBIDO: enero de 2020; ACEPTADo: marzo de 2020 


\section{VÍDEOS}

1. Venir (octubre 2011)

Dirección: Roberto Doveris

Dirección de arte: Víctor Almendra

Niña Niño Producciones

2. Niños rosados (febrero 2014)

Dirección: Víctor Almendra

Dirección de arte: Mara Solís de Ovando

Pirata Prod.

3. VArita mágica (mayo 2014)

Dirección: Jean Vargas

Javier Mancilla Producciones

4. LA FiEsta (septiembre 2014)

Dirección: Jorge Candia

Dirección de arte: Valentina Oyarzun

Realizado por Planeador Prod.

5. • (junio 2015)

Dirección y producción: Víctor Almendra

Dirección de arte: Flor San Martín

Coproduce: Late Producción

6. Hormonas (septiembre 2015)

Dirección: Benjy Estrada

Los Niños Perdidos, México 2014-2015

7. Baila como hombre (lyric video) (octubre 2015)

Realización: ChocoChips Lab

8. Final de temporada (noviembre 2015)

Realización: ChocoChips Lab / Nicolás Montenegro

La Vaca Infinita

9. Baila сомо номвre / Homenaje a Daniel Zamudio (abril 2016)

Audiovisual a cargo de Valentina Andrade y Guillermo Pastenes

10. Sol, cuídate (junio 2016)

Dirección de arte: Roberto Riveros y Marita Aravena

Realización: MILKY!

11. LAS POLILlas (agosto 2016)

Dirección: Bernardo Quesney

Dirección de arte: Camila Rey 
Diego Carrasco Prod.

Realizado por MILKY!

12. Hijos del Peligro (noviembre 2016)

Dirección: Roberto Doveris

Dirección de arte: Diana Matus

Niña Niño Producciones

13. Edificios (septiembre 2017)

Dirección: Felipe Reuters de la Maza

Dirección de arte: Francisca Correa

Prímate Lab

14. El valor (julio 2018)

Realización: Diego Lomelín

15. El dolor es un momento. El valor es la fogata (septiembre 2018)

Dirección: Matías Bize

Bailada, discutida y vivida: las Vulvas furiosas

Producción El Sol

16. Lo importante (enero 2020)

Dirección: Cristobal León

Dirección de arte: Natalia Geisse

Producción: Cristobal León / Diluvio 


\section{FUENTES UTILIZADAS}

\section{Libros y ARTí́culos}

Barker, M.-J. y Scheele, J. (2017): Queer una historia gráfica, Santa Cruz de Tenerife, Melusina. Bernini, L. (2018): Las Teorias Queer. Una introducción, Barcelona-Madrid, Egales.

ButLer, J. (2007): El género en disputa: el feminismo y la subversión de la identidad, Barcelona, Paidós. Dolera, L. (2018): Morder la manzana. La revolución será feminista o no será, Barcelona, Planeta.

Garrandés, A. (2016): El espejo roto. Morfologías del cuerpo gay-lesbianolqueer en el cine, La Habana, ICAIC.

Halberstam, J. (2011): El arte queer del fracaso. Barcelona-Madrid, Egales.

Herrera, C. (2019): Hombres que ya no hacen sufrir por amor. Transformando las masculinidades. Madrid, Los Libros de la Catarata.

Kunn, A. y Westwell, G. (2012): Oxford Dictionary of Film Studies. Oxford, Oxford University Press.

Martín, G.J. (2016): Quiérete mucho, maricón: Manual del éxito psicoemocional para hombres homosexuales. [Kindle Android Version]. Retrieved from Amazon.com

Palencia, L. (2008): Hollywood Queer, Madrid, T\&B.

Preciado, B. (2012): Devenir bollo-lobo o cómo hacerse un cuerpo queer a partir del pensamiento heterosexual. En Teoría Queer (G). [Kindle IOS Version]. Retrieved from Amazon.com.

Sáez, J., Vidarte, P. y Córdoba, D. (2012) (ed.): Teoría Queer (G). [Kindle IOS Version]. Retrieved from Amazon.com.

ZADÚ, I. (2009, 1 de diciembre): «Feminismo y Teoría Queer», SOB Socialismo o barbarie, Buenos Aires.

\section{Blogs y REVistas digitales}

Alfaro Farías, F. (2017, 19 de octubre). Editorial (Me llamo) Sebastián: Esto recién comienza. Cancha General. Recuperado de http://canchageneral.com/me-llamo-sebastian-teatro-cariola/.

Bside, F. (2020, 9 de enero). [Lo importante] (Me llamo) Sebastián nos lleva a fijarnos en lo que realmente importa. Confesiones tirado en la pista de baile. Recuperado de http://confesionestiradoenlapistadebaile.blogspot.com/2020/01/lo-importante-me-llamo-sebastian-nos.html.

Carvancho, B. (2017, 27 de julio). Entrevista: (Me llamo) Sebastián: «El arma más potente de este patriarcado es la violencia de la imposición». Tercera. Recuperado de http://www2. latercera.com/noticia/me-llamo-sebastian-arma-mas-potente-este-patriarcado-la-violencia-la-imposicion/.

Del Real, A. (2017, 6 de septiembre). Entrevista: (Me llamo) Sebastián lanza en octubre el disco que expone su lado oscuro. Culto-La Tercera. Recuperado de http://culto.latercera. com/2017/09/06/me-llamo-sebastian-lanza-en-octubre-disco-expone-lado-oscuro/.

Del Real, A. (2017, 18 de noviembre). Entrevista: (me llamo) Sebastián: «Me da pena que todo lo que he hecho se vea manchado». Culto-La Tercera. Recuperado de http://culto.latercera. com/2017/11/16/me-llamo-sebastian-me-da-pena-lo-he-hecho-se-vea-manchado/. 
Del Real, A. (2018, 5 de diciembre). (Me llamo) Sebastián se radica en México tras la polémica. CULTO. Recuperado de https://www.google.es/amp/s/culto.latercera.com/2018/05/12/ me-llamo-sebastian-se-radica-en-mexico-tras-la-polemicaa/amp/.

Equipo Rock \& Pop (2017, 23 de noviembre). Alex Anwandter disparó contra vocalista de Planeta No. «Entiendo la rabia y la decepción». Rockandpop. Recuperado de https://www.rockandpop. cl/2017/11/alex-anwandter-disparo-vocalista-planeta-no-entiendo-la-rabia-la-decepcion/.

García, B. (2016, 25 de agosto). (Me llamo) Sebastián habla de su nuevo single y resta importancia al rango vocal dentro del pop. Tendencias Tele13. Recuperado de http://www.t13.cl/noticia/tendencias/espectaculos/me-llamo-sebastian-las-polillas-entrevista.

García, M. (2015, 4 de mayo). El oído intercontinental de Mowat. SUPER45.cl. Recuperado de https://super45.cl/articulos/entrevistas/el-oido-intercontinental-de-mowat/.

Garrido, M. (2017, 10 de noviembre). Entrevista: Javiera Mena y músicos apuntados por acoso: «Estamos acostumbrados a tirar piedras y me parece bien esperar». Culto-La Tercera. Recuperado de http://culto.latercera.com/2017/11/10/javiera-mena-musicos-apuntados-acoso-estamos-acostumbrados-a-tirar-tirar-piedras-me-parece-bien-esperar/.

Jones, Z. \& B. (2014, 4 de noviembre). Entrevista: (me llamo) Sebastián-Varita mágica. Zambombazo: Lengua, música y cultura. Recuperado de http://zachary-jones.com/zambombazo/cancionero-me-llamo-sebastian-varita-magica/.

Legorreta, G. (2015, 2 de septiembre). Entrevista: De paseo con: (Me llamo) Sebastián. México. Young Offenders. Recuperado de http://young-offenders.com/entrevista-a-me-llamo-sebastian/.

León, P. (2019, 5 de noviembre). Ley Zamudio. Una normativa insuficiente para frenar la violencia. Diario U Chile. Recuperado de https://radio.uchile.cl/2019/03/24/ley-zamudio-una-normativa-insuficiente-para-frenar-la-violencia/.

Littlebab (2016, 28 de octubre). (Me llamo) Sebastián: «encasillarnos en categorías no hace bien a nadie». Estoybailando.com. Recuperado de http://estoybailando.com/me-llamo-sebastian-encasillarnos-en-categorias-no-hace-bien-a-nadie/.

Marcelo (2013, 31 de julio). Entrevista a: (Me llamo) Sebastián: «La obra pone palabras a una generación». Alavena.cl. Recuperado de http://www.alavena.cl/2013/07/entrevista-a-me-llamo-sebastian-la-obra-pone-palabras-a-una-generacion/.

Millavil, M. (2013, 20 de diciembre). Entrevista a (Me llamo) Sebastián: «Estoy contenido para entregar un material más íntimo». POTQ Magazine. Recuperado de https://www.potq.net/ entrevistas/me-llamo-sebastian-estoy-contenido-para-entregar-un-material-mas-intimo/.

Morales, J.F. (2016, 23 de diciembre). Entrevista con (me llamo Sebastián): las etiquetas las pone otra gente no yo. Mor.bo, convergencia cultural. Recuperado de http://ismorbo.com/entrevista-con-me-llamo-sebastian-un-concierto-bacan-puede-cambiarte-la-vida/.

Ocampo Cea, A. (2014, 28 de marzo). Entrevistas: (me llamo) Sebastián, el niño rosado. Noisey. Recuperado de http://noisey.vice.com/es_mx/article/me-llamo-sebastin-el-niño-rosado.

Ocampo, A. y Ocampo Cea, A. (2016, 22 de noviembre). Entrevista a (me llamo) Sebastián. NOISEY Music by Vice. Recuperado de https://www.vice.com/es_latam/article/7bxm8z/pop-que-conmemora-el-tiroteo-de-orlando-me-llamo-sebastian-y-roberto-doveris-son-los-hijos-del-peligro. 
Mundo Películas Tv (2018, 28 de septiembre). Matías Bize dirige nuevo video de Me Llamo Sebastián. Mundo Películas Tv. Recuperado de https://www.mundopeliculas.tv/ 2018/09/28/ video-matias-bize-dirige-nuevo-video-de-me-llamo-sebastian/.

Planet, G. (2016, 26 de enero). Radar Latino. (Me llamo) Sebastián, revolución musical y sexual en Chile. El Pais. Recuperado de http://cultura.elpais.com/cultura/2016/01/26/actualidad/1453813833_572183.html.

P.R. (2016, 14 de noviembre). Me llamo (Sebastián) estrena nuevo single con dramático videoclip. La Tercera. Recuperado de http://www2.latercera.com/noticia/me-llamo-sebastian-lanza-nuevo-single-dramatico-videoclip.

Reyes, P. (2017, 4 de octubre). (Me llamo) Sebastián estrena video. Culto-La Tercera. Recuperado de http://culto.latercera.com/2017/10/04/me-llamo-sebastian-estrena-video/.

Rifo, C. (2017, 4 de junio). (Me llamo) Sebastián. Entrevista. Picnic. Recuperado de https://www. potq.net/noticias/me-llamo-sebastian-picnic-encuentro-ridiculo-exista-gente-trans-no-haya-leyes-cuidarlos/.

Riveros, V. (2017, 31 de mayo). Entrevista: «La música tiene un poder»: (Me llamo) Sebastián en su fugaz paso por Conce. Rockcity. Recuperado de http://rockcity.cl/2017/05/16/la-musica-igual-tiene-un-poder-me-llamo-sebastian-en-su-fugaz-paso-por-conce/.

Rubio Sotos, (2015, 2 de agosto). (me llamo) Sebastián: La belleza. ZdeO. Zona de Obras. Culturas Contemporáneas de España y Latinoamérica a diario. Recuperado de https://www.zonadeobras.com/?s=2+agosto +2015 .

SAnta Cruz, B. (2016, 28 de mayo). Entrevista: (Me llamo) Sebastián/ «Soy un defensor del cariño». Revista Ruda. Recuperado de http://www.revistaruda.cl/me-llamo-sebastian-soy-un-defensor-del-carino/.

Valencia, P. (2017, 29 de septiembre). Entrevista: Humanamente hablando con (me llamo) Sebastián: "Me identifica lo dark desde que era gordito que odiaba todo, medio Daria». Pousta. Recuperado de https://pousta.com/me-llamo-sebastian-entrevista/.

Vidal, V. (2014, 28 de enero). El pop confesional de (me llamo) Sebastián. Revista Paula. Recuperado de http://paula.cl/tiempo-libre/el-pop-confesional-de-me-llamo-sebastian/.

Villegas, R. (2017, 17 de octubre). (Me llamo) Sebastian's New Álbum 'La Sombra' Tackles Queer Life and Death in Chile. Reseńa del disco. Remezcla. Recuperado de http://remezcla.com/ relevases/music/me-llamo-sebastian-la-sombra-review/. 
